What Does the Yield on Subordinated Bank Debt Measure?

Urs W. Birchler and Diana Hancock

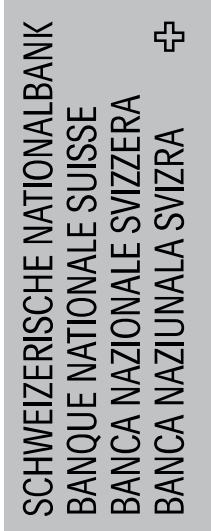

U

(1)

잉

ro

Q

$\frac{0}{2}$



$\frac{n}{3}$ 
The views expressed in this paper are those of the author(s) and do not necessarily represent those of the Swiss National Bank. Working Papers describe research in progress. Their aim is to elicit comments and to further debate.

ISSN $1660-7716$

๑ 2004 by Swiss National Bank, Börsenstrasse 15, P.0. Box, CH-8022 Zurich 


\title{
What Does the Yield on Subordinated Bank Debt Measure?
}

\author{
URS W. Birchler AND DiAnA HANCOCK*
}

December 18, 2003

\begin{abstract}
We provide evidence that a bank's subordinated debt yield spread is not, by itself, a sufficient measure of default risk. We use a model in which subordinated debt is held by investors with superior knowledge ("informed investor hypothesis"). First, we show that in theory the yield spread on subordinated debt must compensate investors for expected loss plus give them an incentive not to prefer senior debt. Second we present strong empirical evidence in favor of the informed investor hypothesis and of the existence of the incentive premium predicted by the model. Using data on the timing and pricing of public debt issues made by large U.S. banking organizations during the 1985-2002 period, we find that banks issue relatively more subordinated debt in good times, i.e. when informed investors have good news. Spreads at issuance (corrected for sample selection bias) react to (superior) private and to public information, in line with the comparative statics of the postulated incentive premium. Interestingly, as the model predicts, the influence of sophisticated investors' information on the subordinated yield spread became weaker after the introduction of prompt corrective action and depositor preference reforms, while the influence of public risk perception grew stronger. Finally, our model explains anomalies from the empirical literature on subordinated debt spreads and from market interviews (e.g. limited sensitivity to bank-specific risk and the "ballooning" of spreads in bad times). We conclude that a bank's subordinated yield spread conveys important information if interpreted together with its senior spread and with other banks' subordinated yield spreads.
\end{abstract}

KEYWORDS: market discipline, subordinated debt, bank supervision. JEL-CLASSIFICATIONS: D8, G2, K2

\footnotetext{
*For helpful comments we are indebted to Kathleen McDill, to Myron Kwast, to Matteo Facchinetti, to participants in the Basel Committee research workshop at Banca d'Italia, Rome 2003, and to seminar participants at Université de Lausanne, at Österreichische Nationalbank, at Universität St. Gallen, and at the European Economic Association annual meeting in Lausanne (2001). Excellent research assistance was provided by Laura Kawano. The views expressed here are those of the authors and do not necessarily reflect those of the Board of Governors, the Swiss National Bank, or their respective staff.

Authors' Information: Urs Birchler [Address: Swiss National Bank, Börsenstrasse 15, 8001 Zürich; e-mail: urs.birchler@snb.ch; Phone: +41 163134 26; Fax: +41 163181 09] and Diana Hancock [Address: Mail Stop 153, Board of Governors of the Federal Reserve System, Washington, DC 20551; e-mail: Diana.Hancock@frb.gov; Phone: (202) 452-3019; Fax: (202) $452-5295]$.
} 


\section{Introduction}

Over the last few years, economists have intensely debated the role of subordinated debt as a vehicle for improved market discipline in banking. ${ }^{1}$ Some authors advocate mandatory issuance of subordinated debt instruments by banks. ${ }^{2}$ Other proposals focus on the so-called yield spread, i.e., the difference between the yield on a subordinated instrument and the yield of a comparable risk-free bond (like government debt). This yield spread is generally considered to be a good measure of bank risk, as the holders of subordinated debt absorb the first loss (after shareholders) in the event of a bank failure. Consequently, some authors have proposed a regulatory ceiling on banks' subordinated yield spreads (Calomiris, 1999) while others have argued that they would use such a spread as an early warning signal and as a trigger for prompt corrective actions (Evanoff and Wall, 2000).

Taking stock with respect to the ongoing debate, BoG/DoT (2000) concluded that supervisory authorities would continue, "as part of the supervisory process, to monitor both yields and issuance patterns of individual institutions" (BoG/DoT, 2000, p. iv). Hence, it is of crucial importance to know what observed yields and issuance patterns really foretell.

Proponents, as well as opponents, of mandatory subordinated debt proposals seem to agree that, in theory at least, the subordinated debt spread measures bank risk defined as the expected loss to investors (i.e., the probability of default times the loss given default). ${ }^{3}$ In practice, subordinated bond spreads may be distorted by several factors: individual instrument characteristics, poor market liquidity, investors' risk aversion, and fluctuations in the market price of risk. ${ }^{4}$ In the absence of such disturbances, however, for most participants in the debate the subordinated bond yield spread accurately measures a bank's risk.

In this paper, we try to show that the subordinated debt spread by itself is not a sufficient measure of a bank's default risk, since it is only meaningful when it is used with both senior debt spreads and subordinated debt spreads at other banks. Our starting point is the observation that subordinated debt, by its very definition, does not exist alone, but only as one of at least a pair of debt instruments. It is thus important to first understand the reason for the existence of dual debt before any inferences about yields are made. There are several reasons why a bank may want to issue dual class debt, including reasons that build on the heterogeneity of either investors, or of banks (see, e.g. Diamond, 1993; Barclay and Smith, 1995; Winton, 1995; Birchler, 2000).

\footnotetext{
${ }^{1}$ For an overview, see Board of Governors of the Federal Reserve System (BoG) (1999) and Board of Governors of the Federal Reserve System and United States Department of Treasury (BoG/DoT) (2000).

${ }^{2}$ For a textbook discussion of the incentive effects of subordinated debt, see Dewatripont and Tirole (1994), section 13.3.1.

${ }^{3}$ See, for example, Campbell and Huisman (2003).

${ }^{4}$ Elton, Gruber, Agrawal and Mann (2001) estimate that less than 25 percent of corporate spot spreads can be explained by expected default losses. They also demonstrate that the sensitivity to factors commonly used to explain risk premiums in common stocks explains between 66 percent and 85 percent of the spread in corporate and government rates that is not explained by the difference in promised and expected payments and taxes. By these calculations, 15 to 34 percent of a typical corporate bond spread is left unexplained. In addition, Hancock and Kwast (2000) report that subordinated debt spreads for large U.S. banking organizations are sensitive to systematic risk factors such as stock market excess returns.
} 
In what follows we will focus on the heterogeneity of investors. Our model assumes that some investors have superior information. ${ }^{5}$ This assumption fits well with the different subordinated debt proposals: Subordinated debt can provide market discipline only if its potential holders know more about the quality of a bank than do other investors. The "informed investor hypothesis" also fits the data well: We find strong empirical support for this assumption in the pricing of public debt issues made by large U.S. banking organizations in the 1985-2002 period.

In addition, our model allows for differences in risk appetite (i.e., the "risk aversion hypothesis"), for which we find less empirical support. And, an alternative hypothesis - the "informed bank, or signalling hypothesis" - where banks signal earnings prospects by choosing to issue either senior or subordinated debt (see Barclay and Smith, 1995) is rejected by bond market data for large U.S. banking organizations.

Regardless of the reason that a firm wants to issue subordinated and senior debt, it must make both instruments sufficiently attractive for the respective investors. Subordinated debt must "beat" not only risk-free alternatives, e.g., a Treasury bond, but, also must "beat" in the eyes of some investors its own sister, senior debt. This is why its equilibrium yield spread contains not only a risk premium (to make subordinated debt attractive compared to the risk-free asset), but also an "incentive premium" (to compete with senior debt). Under the informed investor hypothesis the incentive premium can be thought of as an information rent earned by investors who have favorable information about the issuer. ${ }^{6}$ Under the risk aversion hypothesis, senior debt pays a higher risk premium which, like the incentive premium, also carries forward to the yield on subordinated debt, even though the latter may be held by risk neutral agents.

We reject claims that subordinated debt spreads measure a bank's risk as perceived by sophisticated investors. Instead, our results almost literally support views formulated by market participats that signals from subordinated debt spreads are jammed by movements in general market sentiment. ${ }^{7}$ Our model shows that this "noise" reflects completely rational behavior on the part of investors, notwithstanding the doubts of some observers. ${ }^{8}$ In addition, our model yields predictions on banks' issuance policies for subordinated and for senior debt. According to the informed investor hypothesis, a bank would issue subordinated debt upon receipt of good news and it would issue senior debt

\footnotetext{
${ }^{5}$ Diversity of information, and thus of opinion, probably is a factor behind the existence of many financial contracts and institutions (Allen and Gale, 2000) and behind some phenomena of asset pricing (Diether, Malloy and Scherbina, 2002).

${ }^{6}$ It is a well known result from contracting models that among heterogeneous agents those with superior information earn an information rent.

${ }^{7}$ In response to a request for comments on the feasibility and appropriateness of a mandatory subordinated debt policy, a U.S. Bank Holding Company stated that: "(T)he practical issues associated with distentangling the separate influences of market factors and of changes in the risk profile of a financial institution on its debt spreads would make such debt spreads a poor tool for supervisory monitoring purposes." (BoG/DoT, 2000, p. 78). Moreover, market participants have noted that: "Spreads need to be interpreted with great care. For example, the general level of spreads is quite sensitive to cyclical fluctuations. In good times, spreads tend to be rather narrow, reflecting the view that all banks and bank holding companies are in good shape. In bad times, spreads balloon, reflecting broad skepticism regarding the financial health of banking institutions." (BoG, 1999, p. 16.)

${ }^{8}$ In 2002, a U.S. Bank Examiner lamented: "The time-series movements of observed subordinated debt spreads do not reflect changes in supervisory information. It almost seems like stupid people buy and sell these bonds."
} 
upon receipt of unfavorable news. This is because the bank would issue debt of different priority status to separate investors with different, yet unobservable, beliefs on the probability of its failure. Our analysis of U.S. bond market data on the timing of public debt issues by large banking organizations suggests that the health of the organization influences its bond issuance decisions, and these decisions are usually consistent with the informed investor hypothesis.

One reason we focus on U.S. banking organizations over the 1985-2002 period is because two regulatory reforms - capital-based prompt corrective actions by bank supervisors (initiated by the Federal Deposit Insurance Corporation Improvement Act, FDICIA) and depositor preference rules (which established a clear priority for the distribution of (unsecured) claims realized from the liquidation or other resolution of any insured depository) were implemented approximately in the middle of the sample period. These reforms would, of course, influence investors' perceptions about the likelihood of bank failures and their prospective losses when bank defaults occur. As will be seen below, these perceptions importantly influence the magnitude of the incentive premium contained in subordinated debt yields.

Our paper is structured as follows: In Section 2, we introduce our theoretical model of the subordinated debt spread. In Section 3 we present the empirical evidence on the risk-sensitivity of the issuance decision and of subordinated debt spreads. In section 4, we discuss our results. And, section 5 concludes.

\section{The model}

\subsection{Assumptions}

There are several reasons why a bank may want to issue debt instruments that differ with respect to their rank in the event of an insolvency. ${ }^{9}$ A plausible explanation for the existence of dual class bank debt is heterogeneity of investors. These individuals may differ in their preferences, wealth, sophistication, or information. In what follows, we will focus on differences in investor opinion assuming that some investors have superior information (i.e., the "informed investor hypothesis"). In addition, we allow for differences in risk taste (i.e., the "risk aversion hypothesis"). Unobservable heterogeneity of investors provides the basis for partial investor separation through the use of dual debt, i.e., of a senior and a subordinated instrument.

We use a variation of the Birchler (2000) model for the use of dual debt instruments by a bank borrowing from investors having different information. In this model, a bank can invest in a single one-period asset. The asset has an observable but uncertain per dollar return $y \in\{\bar{Y}, \underline{Y}\}$ with $\bar{Y}>R>\underline{Y}$, where $R$ is the return on a riskfree asset. We denote the prior probability of "success" by $p=\operatorname{prob}\{\bar{Y}\}>0.5$. The bank has no funds of its own, i.e. it has strictly limited liability. In order to invest, the bank has to borrow from a large number of small investors. We normalize their aggregate funds to one dollar. The bank offers investors contracts on a "take-it-or-leave-it" basis. After contracts are offered, but before investors have decided to invest or not, the bank as well as some sophisticated investors get a signal on the project's probability of success. The signal updates $p$ to either $q(>p)$ (good news) or $(1-q)$ (bad

\footnotetext{
${ }^{9}$ For a short overview of the literature on debt priorities, see Birchler (2000).
} 
news). We denote the fraction of informed investors by $h$, of whom fraction $u$ get a good signal, and $(1-u)$ get a bad signal. Setting $p=u q+(1-u)(1-q)$ we assure that the different beliefs are consistent. We assume that all investors are risk-neutral, but we will relax this assumption below.

At the time the bank offers contracts, it faces three potential types of investors: optimists $(\operatorname{prob}\{\bar{Y}\}=q)$, uninformed $(\operatorname{prob}\{\bar{Y}\}=p)$, and pessimists $(\operatorname{prob}\{\bar{Y}\}=(1-q))$. In expected terms the three groups have size $h u$ (optimists), $(1-h)$ (uninformed), and $h(1-u)$ (pessimists), respectively. Even after the signal has occurred, the bank cannot distinguish investors. Yet, by appropriate design of contracts, the bank can partly separate investors, i.e., it can attract some but not others. ${ }^{10}$

We restrict asset payoffs to make sure that:

1. The bank finds it worthwhile to borrow from uninformed investors and, $a$ fortiori, from optimists - a sufficient condition is that $p \bar{Y}+(1-p) \underline{Y}>R$;

2. The bank does not borrow from pessimists ${ }^{11}$ - a sufficient condition is $(1-q) \bar{Y}+q \underline{Y}<R ;$ and,

3. The bank cannot offer risk free contracts, even if all income in case of failure $(\underline{Y})$ is promised to uninformed investors - a sufficient condition is: $R>\underline{Y} /(1-k)$, where $k=(1-h) /[(1-h)+u h]$, the fraction of uninformed in total depositors.

These assumptions also ensure that the bank is solvent if realized $y=\bar{Y}$ and insolvent if realized $y=\underline{Y}$.

\subsection{Contracts}

Contracts can be written only on observable outcomes, not on (unobservable) types of investors. The bank can offer two contracts to separate the optimists from the uninformed investors. The contract menu can be written as

$$
\mathbf{C}=\left\{\mathbf{c}_{1}(\bar{Y}, \underline{Y}), \mathbf{c}_{2}(\bar{Y}, \underline{Y})\right\}
$$

where the two elements, $\mathbf{c}_{1}$ and $\mathbf{c}_{2}$, represent senior (i.e., non-subordinated) $\operatorname{debt}\left(\mathbf{c}_{1}\right)$ and junior (i.e., subordinated) debt $\left(\mathbf{c}_{2}\right)$. It will turn out that uninformed investors prefer the senior contract, which is served first in the event of failure, while optimists prefer the subordinated contract, which pays more when the banks' project succeeds and the bank does not fail. The bank thus borrows from $u h$ informed and from $1-h$ uninformed investors. The fraction of informed investors in total lenders (as distinct from the fraction in total potential investors) thus is $k=h /[(1-h)+u h]$.

We will refer to success and failure payments promised under contract $i$ as $D_{i}$ (face value of debt) and $M_{i}$ (minimum repayment). The two contracts thus are

$$
\mathbf{c}_{1}=\left\{D_{1}, M_{1}\right\} \text { and } \mathbf{c}_{2}=\left\{D_{2}, M_{2}\right\} .
$$

\footnotetext{
${ }^{10}$ Given any set of contracts, the bank, due to its limited liability, would borrow from all groups of investors (as long as it promises less than $\bar{Y}$ ).

${ }^{11}$ In our model pessimists' beliefs do not influence debt spreads; pessimists can only decide not to buy debt, but they cannot sell bank debt short. Diether, Malloy and Scherbina (2002) use a more elaborate model of heterogeneous beliefs in which the more pessimistic expectations are not reflected in (stock) prices due to short selling constraints.
} 
The bank offers the contract menu that maximizes expected profit conditional on investors' rational investment strategies and on the prior probability of success $p$. The bank thus solves

$$
\max _{D_{1}, M_{1}, D_{2}, M_{2}} p\left[\bar{Y}-k D_{2}-(1-k) D_{1}\right]+(1-p)\left[\underline{Y}-k M_{2}-(1-k) M_{1}\right]
$$

subject to participation constraints for both groups of investors ((2) and (3)); to incentive, or self selection, constraints ensuring that each group prefers the "right" contract ((4) and (5)); as well as to limited liability, or wealth, constraints ((6) through (9)).

$$
\begin{gathered}
p D_{1}+(1-p) M_{1}-R \geq 0 \\
q D_{2}+(1-q) M_{2}-R \geq 0 \\
p D_{1}+(1-p) M_{1} \geq p D_{2}+(1-p) M_{2} \\
q D_{2}+(1-q) M_{2} \geq q D_{1}+(1-q) M_{1} \\
\\
\bar{Y}-k D_{2}-(1-k) D_{1} \geq 0 \\
\underline{Y}-k M_{2}-(1-k) M_{1} \geq 0 \\
D_{1} \geq 0, M_{1} \geq 0 \\
D_{2} \geq 0, M_{2} \geq 0
\end{gathered}
$$

Proposition 1 (The optimal contract). The banker offers dual debt consisting of a senior contract $\mathbf{c}_{1}=\left\{D_{1}, M_{1}\right\}$, and a subordinated contract, $\mathbf{c}_{2}=$ $\left\{D_{2}, M_{2}\right\}$ with payoffs $D$ in the event of success, and $M$ in the event of the banks' failure, where

$$
\begin{aligned}
D_{1} & =\frac{1}{p} R-\frac{1-p}{p} M_{1} \\
M_{1} & =\frac{1}{(1-k)} \underline{Y} \\
D_{2} & =\frac{1}{p} R-\frac{q-p}{q p} M_{1} \\
M_{2} & =0
\end{aligned}
$$

\section{Proof.}

The marginal rates of substitution between success and failure income for the bank, optimists and uninformed investors are $M R S_{\text {bank }}=-(1-p) / p$, $M R S_{g}=-(1-q) / q$ and $M R S_{n}>-(1-p) / p$, respectively. Therefore $M R S_{g}<$ $M R S_{\text {bank }}<M R S_{n}$. Of all three parties, uninformed investors thus attach the highest relative weight to income in case of failure. Therefore, they get all of $\underline{Y}$, plus a share of $\bar{Y}$ necessary to satisfy their participation constraint (2). Optimists get enough for (a) participation and (b) for not preferring $\mathbf{c}_{1}$; as (5) is more restrictive than (3), (b) binds, hence the solution for $D_{2}$. 
The two debt instruments are represented graphically in Figure 2.1. Lines $p$ and $q$ are indifference curves for uninformed investors and for optimists, respectively. As these indifference curves run through $(R, R)$, they are the relevant participation constraints. The senior instrument, $\left\{D_{1}, M_{1}\right\}$, just satisfies the participation constraint of uninformed investors. These investors get all available returns in the event of a bank failure, when total return $\underline{Y}$ is divided among the uninformed investors. ${ }^{12}$ Subordinated investors get nothing in the event of a failure. ${ }^{13}$ In the event of success, they must be paid $D_{2}>D_{1}$ to satisfy their incentive or, self-selection, constraint, i.e., their indifference curve $\left(q^{\prime}\right)$ that runs through $\mathbf{c}_{1}$. In contrast, their participation constraint $(q)$ does not bind. It is obvious from Figure 2.1, that the self-selection constraint is more restrictive than is the participation constraint. Subordinated debt thus not only pays $R / q$, but an additional premium $D_{2}-R / q$, to make it attractive relative to senior debt for the optimists. We will call this premium the incentive premium. The fact that the terms of subordinated debt are determined by the incentive constraint, rather than by the participation constraint, is the main theoretical point of this paper. We will use it to explain the impact of changes in different model parameters on the subordinated debt yield spread.

Senior investors might be risk averse instead of, or in addition to being uninformed. Risk aversion would change (2) into:

$$
p\left(D_{1}-\rho\right)+(1-p) M_{1}-R \geq 0
$$

where $\rho$ is the additional risk premium. From Figure 2.2, we can directly tell what the impact of risk aversion on the part of uninformed investors (i.e., senior investors) would be. Under risk aversion the uninformed investors' participation constraint is not represented by the straight line $p$ but by a concave line $p^{\prime}$. The optimal senior contract would thus be become $\mathbf{c}_{1}^{\prime}$. Consequently, the relevant incentive constraint becomes $q^{\prime \prime}$. Subordinated debt holders thus get the same additional risk premium as senior debt holders, even though they are risk neutral! Any factor that increases the risk premium on senior debt also increases the subordinated yield spread by the same amount.

The existence of an incentive premium as part of the subordinated debt yield spread crucially depends on the assumption that the bank cannot distinguish investors by their type. If it could, it could segment markets, which would reduce or, in the extreme, eliminate the incentive premium on subordinated debt. Collin-Dufresne et al. (2001) find in a study on yield spread changes that bond and equity markets might be somewhat segmented. One would also expect segmentation between trade credit and publicly held debt, as public investors cannot pretend to be suppliers and thus potential trade creditors. Some segmentation between senior and subordinated debt markets thus cannot be excluded a priori.

\footnotetext{
${ }^{12}$ There are $(1-k)$ uninformed, while the fraction of informed investors is either $k$ (after a good signal) or 0 (after a bad signal).

${ }^{13}$ This is fairly realistic. For most banks $k$ is small. The fraction of subordinated debt to total assets (a proxy for $k$ ) for major banks in the US and in the EU is reported by Sironi (2001, p. 240) as 2.42 and 1.65 percent, respectively.
} 
Figure 2.1

Senior and Subordinated Debt Yields when

Investors are Risk Neutral

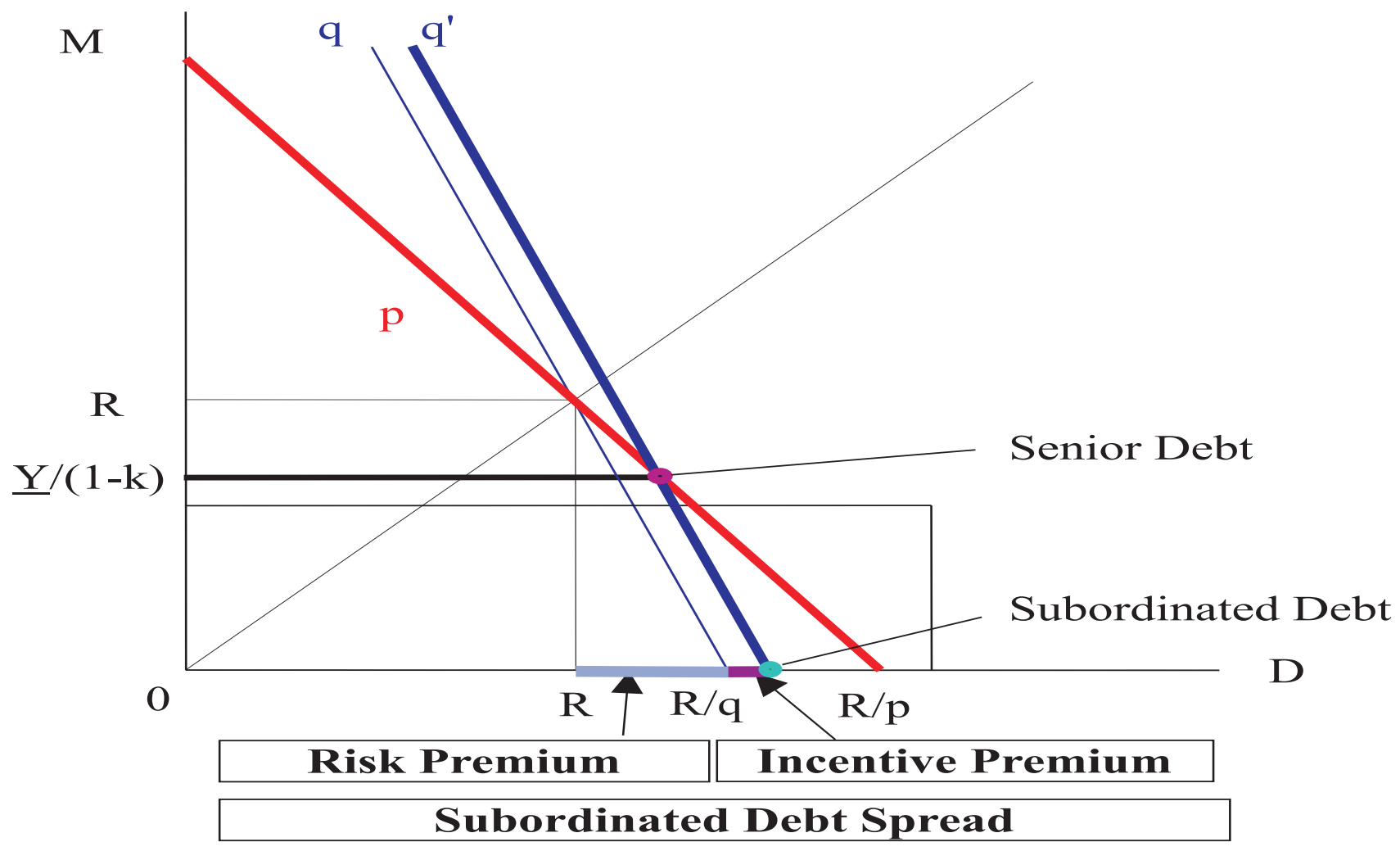

Figure 2.2

Senior and Subordinated Debt Yields when

Investors are Risk Averse

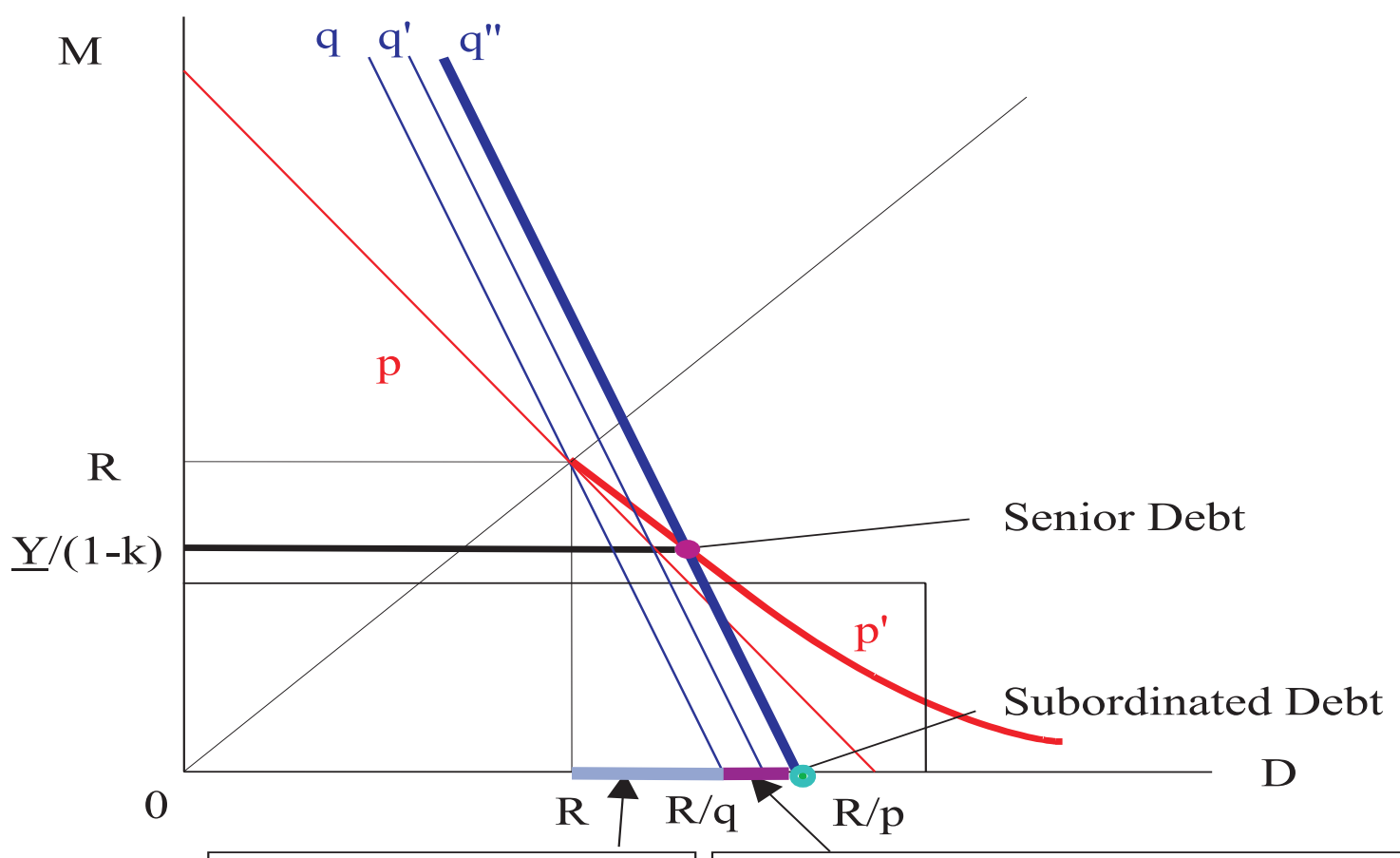

Risk Premium

Incentive Premium Including Risk Aversion 


\subsection{Issuance decisions as a function of the signal}

Strictly speaking, in our model investors decide about the bank's liability structure. After a good signal, both, senior and subordinated debt are sold. After a bad signal, only senior debt is sold. Speaking of the bank's issuance decision makes sense nevertheless. The bank designs and offers contracts; by doing so it implicitly decides under what circumstances it will issue what kind of debt.

The composition of debt issued after the two possible signals, respectively, are represented in Table 2.1 .

Table 2.1

The Amount of Debt Issued as a Function of the Signal

\begin{tabular}{|c|c|c|}
\hline Signal & Senior & Subordinated \\
\hline good & $(1-h) u$ & $h u$ \\
\hline bad & $(1-h) u$ & 0 \\
\hline
\end{tabular}

Given the overly simplistic model, there are only two possible liability structures, only one of which has subordinated debt. For the empirical part of the paper it is sufficient to remember that the model predicts that subordinated debt tends to be issued in good times, while senior debt is the main source of finance in bad times.

\subsection{Equilibrium yield spreads}

The net contractual yield on a debt instrument is the difference between the contractual payment after success minus the original investment, expressed in percentage points of the original investment. ${ }^{14}$ As all payoffs are per dollar and the original investment is one dollar, the yields on the two instruments are $\left(D_{i}-1\right) / 1$. Yield spreads relative to the the safe asset are $\left(D_{i}-R\right)$. For simplicity, we report equilibrium yield spreads for a risk neutral world, bearing in mind that risk aversion of uninformed investors would increase the required spreads on senior and on subordinated debt by $\rho$.

From (10) to (13) we can derive the equilibrium yield spreads on the two instruments. These are:

$$
\begin{aligned}
\delta_{1} & =D_{1}-R=\frac{1-p}{p}\left(R-M_{1}\right) \\
\delta_{2} & =D_{2}-R=\frac{1-p}{p} R-\frac{q-p}{p q} M_{1}
\end{aligned}
$$

Subordinated debt has the higher promised yield than senior debt, the difference being

$$
\delta_{2}-\delta_{1}=\frac{1-q}{q} M_{1}
$$

This difference is the joint effect of two opposing forces: On the one hand, subordinated debt should pay more than senior debt when the bank is solvent,

\footnotetext{
${ }^{14}$ As usual in financial markets, we use "yield" in the sense of contractual, i.e., promised yield (in the event of a success), which is distinct from the expected yield (which includes the possibility of failure).
} 
as it pays nothing in the event that the bank fails. On the other hand, subordinated debt should pay less, since it is held by investors with relatively optimistic expectations. Obviously, the subordination effect is generally stronger than is the expectation effect.

This is confirmed by comparison of the spreads on the two instruments to their actuarially fair values. In a risk neutral world, fair risk premia just provide the investor with an expected return of $R$, the relevant expectation being conditional on his state of knowledge. Fair premia (characterized by a bar) on the two instruments are thus:

$$
\begin{aligned}
& \bar{\delta}_{1}=\bar{D}_{1}-R=\frac{1-p}{p}\left(R-M_{1}\right) \\
& \bar{\delta}_{2}=\bar{D}_{2}-R=\frac{1-q}{q} R
\end{aligned}
$$

The difference between the two fair spreads

$$
\bar{\delta}_{21}=\bar{D}_{2}-\bar{D}_{1}=\frac{1-p}{p} M_{1}-\frac{q-p}{p q} R<0
$$

is negative, as the holders of subordinated debt are relatively optimistic. Further, it is obvious that $D_{1}=\bar{D}_{1}$, and hence $\bar{\delta}_{1}=\delta_{1}$ as (18) is identical to (10). As the senior contract is determined by the participation constraint, it just pays the necessary risk premium. In contrast, (19) is not identical to (12). This leads to the following proposition:

Proposition 2 (The subordinated debt spread). The yield on subordinated debt exceeds the necessary risk premium, i.e.

$$
\delta_{2}>\bar{\delta}_{2}=(1-q) R / q
$$

Proof. The assertion follows directly from (16) and (19).

The bank must promise holders of subordinated debt not just enough to make the subordinated contract (marginally) preferable to the risk free asset; it has to promise more than $R / q$ to make optimists prefer the subordinated contract over the senior contract. The required incentive premium is equal to

$$
\hat{\delta}_{2}=D_{2}-\frac{1}{q} R=\frac{q-p}{p q}\left[R-M_{1}\right]=\frac{q-p}{p q}\left[R-\frac{1}{(1-k)} \underline{Y}\right] .
$$

The incentive premium thus depends on the probabilities of default $p$ and $q$ (i.e., probabilities of default as perceived by uninformed and optimistic investors, respectively) and on the expression in brackets which represents the potential loss on the senior contract, or the "loss given default" in the terminology of BCBS (2001).

The equilibrium spread on the subordinated contract over the yield of the risk-free asset, $\delta_{2}$, can thus be looked at from two sides. On the one hand, it is the sum of the senior spread $\left(\delta_{1}=\bar{\delta}_{1}\right)$ plus the risk premium between subordinated and senior debt. On the other hand, it is the sum of the fair subordinated spread, $\bar{\delta}_{2}$, plus the additional incentive premium, $\hat{\delta}_{2}$, required to induce optimists to prefer the subordinated contract; formally:

$$
\delta_{1}+\delta_{21} \equiv \delta_{2} \equiv \bar{\delta}_{2}+\hat{\delta}_{2}
$$




\subsection{Sensitivity of debt yield spreads to model parameters}

In this section, we look at changes in debt spreads in response to changes in the parameters of our model. For example, the derivatives of the subordinated debt spreads with respect to model parameters $p, q$, and $\underline{Y}$ can be computed from (19), (22), and (16). ${ }^{15}$ These derivatives and those for senior debt are presented in Table 2.2.

Table 2.2 has five rows for each of the spreads under consideration. The derivatives satisfy the same relation as the parameters themselves given in equation (23): The values for the subordinated debt spread $\delta_{2}$ (between double lines) are the sum of the two top rows for the senior spread $\delta_{1}$ and the differential subordinated-senior spread $\delta_{21}$; or, at the same time, of the two bottom rows for the fair subordinated spread $\bar{\delta}_{2}$ and the incentive premium $\hat{\delta}_{2}$.

The columns for the different model parameters reveal several interesting properties of the subordinated debt spread:

1. Sensitivity to public risk perception $(p)$ : The column for $p$ shows, that the subordinated spread, $\delta_{2}$, rises when $p$ falls, i.e., when the risk perceived by the holders of senior debt increases (when the lines $p$ and thus $q^{\prime}$ in Figure 2.1 move counterclockwise around coordinates $(R, R)$ ). The subordinated debt spread thus rises with a deterioration in general market sentiment, even though its holders (as well as the issuer) do not perceive any change in the quality of the bank (i.e., in $q$ ). The (negative) sensitivity of the subordinated yield spread with respect to $p$ is particularly strong, when $p$ is small and when $\underline{Y}$ and $k$ are small (i.e., when the bankruptcy dividend to senior lenders is modest). ${ }^{16}$ Plus, sensitivity to $p$ is strong when senior investors are risk averse, as can be seen in Figure 2.2. The subordinated spread is most sensitive to $p$ when senior investors are risk averse, but do not expect to get much in the event that a bank fails.

2. Sensitivity to informed investors' risk perception $(q)$ : The column for $q$ shows that the subordinated spread, $\delta_{2}$, rises when $q$ falls, i.e., when the risk perceived by subordinated yield holders increases (when lines $q$ and thus $q^{\prime}$ in Figure 2.1 rotate counterclockwise around $\left.(R, R)\right)$. However, the sensitivity of $\delta_{2}$ with respect to $q$ is smaller than the fair risk premium (based on the default probability perceived by holders of subordinated debt) would suggest. This is because the incentive premium, $\hat{\delta}_{2}$, moves in the opposite direction from the default probability perceived by informed investors. The sensitivity of the subordinated spread to $q$ also depends on the senior bankruptcy dividend $(\underline{Y} /(1-k))$ : If senior debt holders expect a bankruptcy dividend that is large (that is, debt holders expect to receive close to the risk-free return, $R$ ), then the subordinated spread is not much above the fair risk premium, $\bar{\delta}_{2}$, and reacts strongly to the default probability perceived by informed investors (i.e., $q$ ). In contrast, if senior debt holders expect a bankruptcy dividend that is small (i.e., close to zero), the incentive premium almost cancels the impact of

\footnotetext{
${ }^{15}$ Recall that $M_{1}=R-\frac{1}{(1-k)} \underline{Y}$.

${ }^{16}$ Recall that $R-\frac{1}{(1-k)} \underline{Y}=R-M_{1}$ is the shortfall of the bankruptcy dividend compared to the risk-free return, and that we assume for simplicity that $k$, the fraction of subordinated debt, is constant. It is also relatively small at most banks.
} 
Table 2.2

Derivatives of Spreads (in rows) with Respect to Model Parameters (in columns)

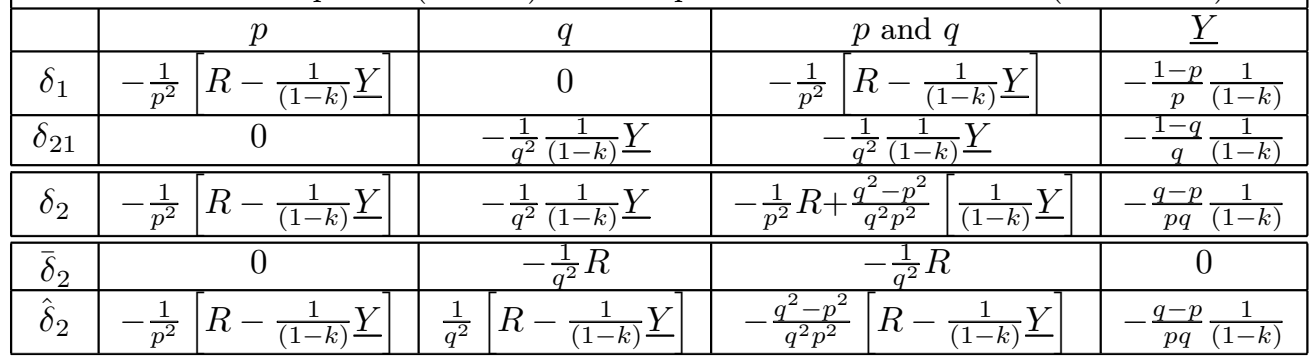


fluctuations in the fair risk premium, and the subordinated yield spread becomes insensitive to the default probability perceived by informed investors (i.e., $q$ ), while remaining sensitive to $p$.

3. Sensitivity to senior lenders' bankruptcy dividend $(\underline{Y} /(1-k))$ : The column for $\underline{Y}$ shows that a higher bankruptcy dividend for senior debt does reduce the senior spread, $\delta_{1}$, and the subordinated spread, $\delta_{2}$. In contrast, the fair risk premium on subordinated debt $\left(\bar{\delta}_{2}\right)$ does not react to changes in $\underline{Y}$, of course. But, via the incentive premium $\left(\hat{\delta}_{2}\right)$, the subordinated spread depends on a payment subordinated investors will never get. It even reacts more strongly to the senior bankruptcy dividend than the senior spread itself. These effects can also be shown in Figure 2.1: The higher the bankruptcy dividend for senior lenders, the lower the payoff senior lenders need to get in the non-default state $\left(D_{1}\right)$, and the higher the necessary incentive premium (as point $\left(D_{1}, D_{2}\right)$ moves to the left). Again, the subordinated spread is more sensitive to the senior bankruptcy dividend if senior investors are risk averse: In Figure 2.2 the subordinated spread falls by a larger amount with an increase in $\underline{Y} /(1-k)$ compared to a corresponing movement in Figure 2.1.

4. Sensitivity to change in regulatory regimes: The implementation of regulatory reforms ${ }^{17}$ during the mid-1990s provides us with an opportunity to consider their potential effects - through simultaneous changes of several model parameters - on observed senior and subordinated debt spreads. On the one hand, $p$ and $q$ have increased, as senior investors may believe that the probability of bank failure is lower in the post-FDICIA period because bank supervisors will undertake prompt corrective actions when the financial condition of a banking organization deteriorates. This perception would result in a smaller incentive premium contained in subordinated debt spreads and in less risk sensitive subordinated debt yields. On the other hand, $\underline{Y} /(1-k)$ has decreased as the lower liquidation standing of senior debt investors, after the implementation of depositor preference rules, would reduce the bankruptcy dividend for senior debt (see Figure 2.3). As the bankruptcy dividend for senior debt falls, the incentive premium contained in subordinated debt spreads increases, while the subordinated spread becomes more sensitive to $p$ and less sensitive to $q$. It is, of course, an empirical question whether these partly opposing forces would cancel one another out, or whether one is much greater than the other.

\subsection{Quantitative importance of the incentive premium}

We have found that, under the informed investor hypothesis, the subordinated yield spread includes an incentive premium of yet unknown size. Before we examine the empirical evidence, we try to get a reasonable guess on the size of the incentive premium we should expect in practice.

From (22) we know that the incentive premium depends on $p, q$, and on the bankruptcy dividend or its complement, the loss given default, for senior debt. For most banks in industrial countries, survival probabilities $p$ and $q$, on

\footnotetext{
${ }^{17}$ For details see below.
} 
Figure 2.3

How did Regulatory Reforms Affect the Incentive Premium?

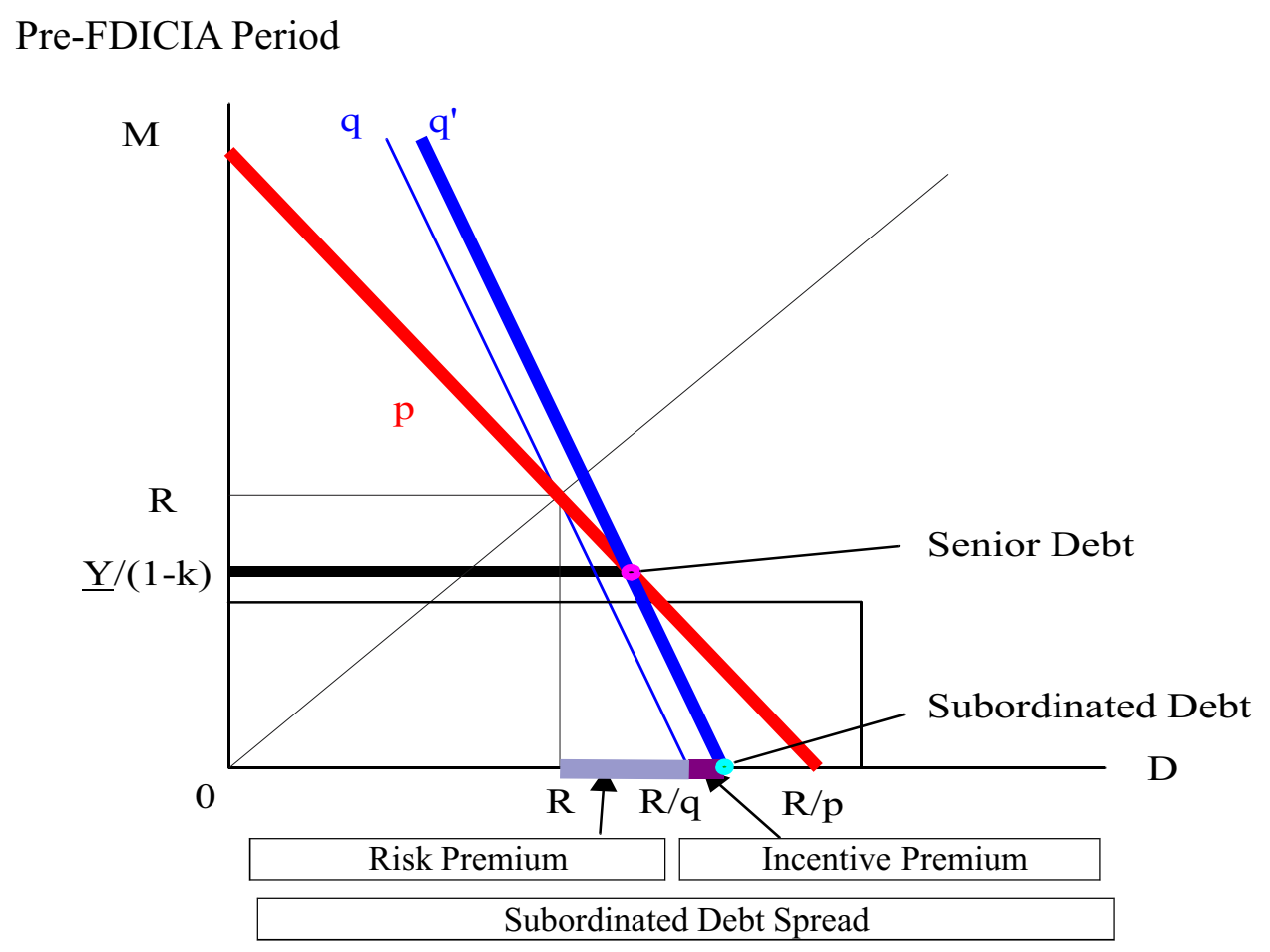

Post-FDICIA Period

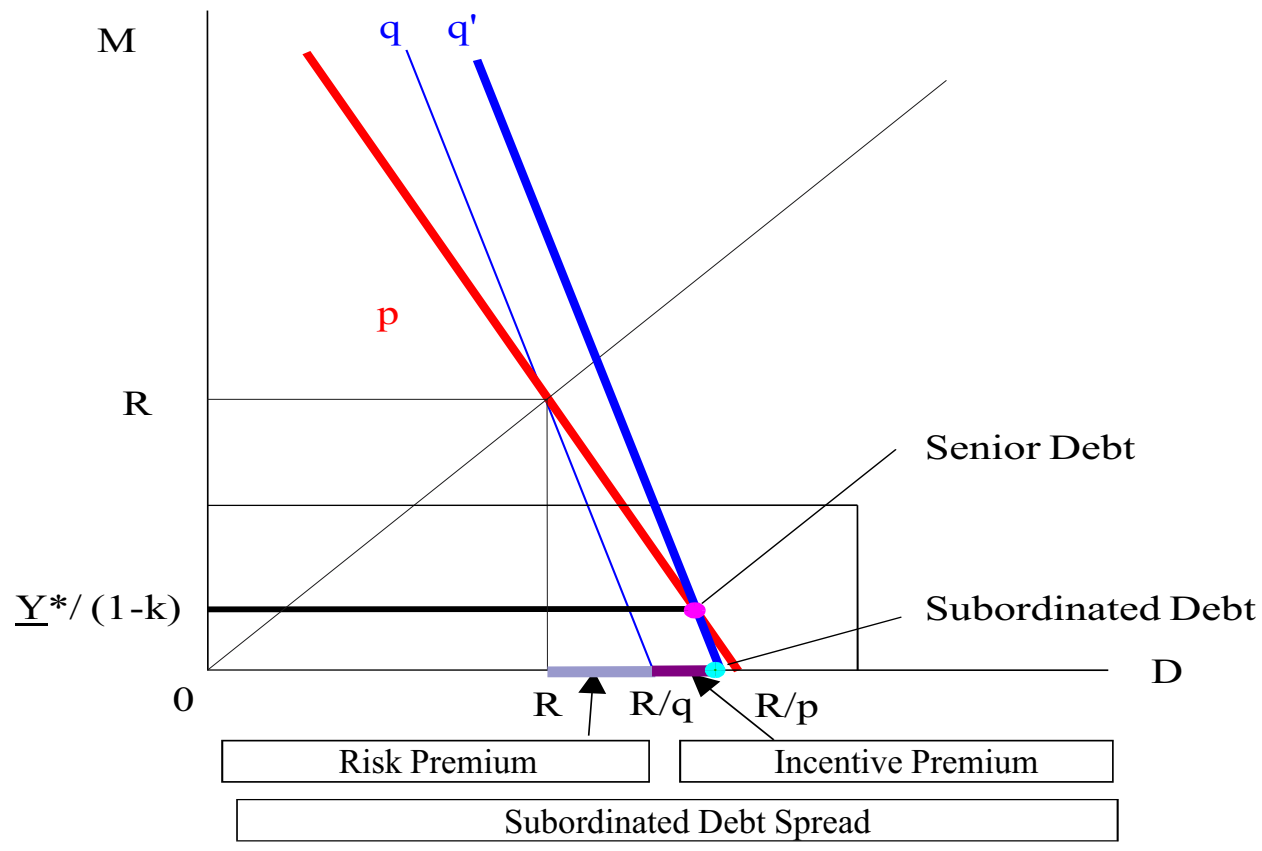


a five to ten year horizon are in the range of 90-99 percent, as implied by KMV data. The denominator in (22) thus can be roughly approximated by unity. The numerator, $p-q$, measuring the difference of opinion between optimists and uninformed investors, depends on the quality of information available to sophisticated investors and to the public, respectively. A few percentage points looks like the upper limit, but 1-2 percent may seem a reasonable guess.

Data for loss given default are available from Moody's (see Table 2.3). For the period 1988-1991 (which falls into the pre-FDICIA period) recovery rates for defaulted debt (in percent of the nominal value of debt) was 26.5 percent on senior debt and 4.9 percent on subordinated debt. ${ }^{18}$

Taken together, these figures would suggest that, in the pre-FDICIA period, incentive premia on subordinated debt for banks in industrialized countries were in the range of 75 to 150 basis points. Hence, incentive premia seem to have similar sizes as liquidity premia (see Covitz, Hancock and Kwast, 2001). Therefore, they should be large enough to leave their traces in the data.

\section{An empirical test of model predictions}

\subsection{Representation of model parameters in the data}

To test our model we have to identify its parameters with observable variables. The key parameters in our model are success probabilities $p$ and $q$, and the expected recovery rate on senior debt, $\underline{Y} /(1-k)$.

For expected recovery rates we have given some point estimates above. For success probabilities, however, we need data on individual banking organizations. More precisely, we need to identify the success probabilities, or rather, the corresponding failure probabilities perceived by informed investors and by uninformed investors, $(1-q)$ and $(1-p)$, respectively, with some empirical risk variables. Thus, our task is to split available risk proxies into information that is only known to relatively sophisticated investors and into information that is publicly known.

\section{Publicly Available Risk Proxies}

Quarterly balance sheet and income statement data for each banking organization $i$ at time $t$ are publicly available from consolidated financial statements for U.S. bank holding companies (FR-Y-9C). These data are reported as of close of business on the last calendar day of the quarter. Risk proxies typically derived from these data include the ratio of nonaccruing loans to total assets $\left(N A T A_{i t}\right)$, the ratio of accruing loans past due 90 days or more to total assets $\left(P D T A_{i t}\right)$, the ratio of other real estate owned to total assets $\left(O R E O_{i t}\right)$, and the absolute value of the difference between assets and liabilities maturing or repricing within one year as a proportion of equity value $\left(A G A P_{i t}\right)$.

Also publicly available are data on the market value of common stock. Using such data together with balance sheet information, the ratio of total

\footnotetext{
${ }^{18}$ Our assumption that subordinated debtholders get nothing in case of failure is thus a reasonable approximation to reality. The data contained in Table 2.2 cover the entire 19852002 period, but there were no large bank failures during the post-FDICIA period.
} 


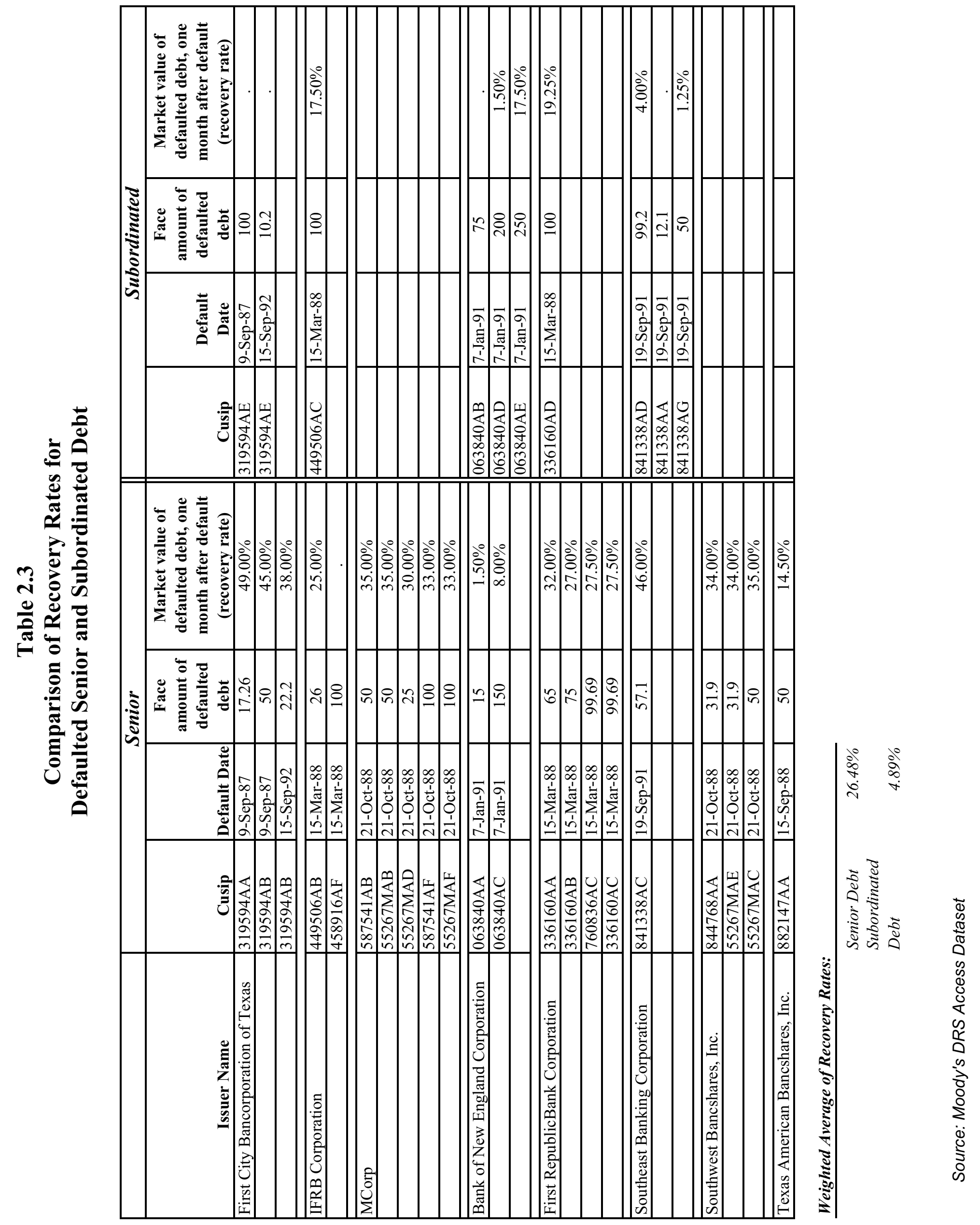


book liabilities to the sum of the market value of common stock and the book value of preferred stock $\left(M K T L E V_{i t}\right)$ can be computed. ${ }^{19}$

While all balance sheet risk proxies are derived from publicly available data, it is not necessarily the case that such information is commonly known. Some risk proxies are highly correlated with widely known information on regional and sectoral business conditions and their magnitude can be easily inferred (e.g., $O R E O_{i t}$ ). Other risk proxies may be so broadly used that they are frequently reported in the press (e.g., $M K$ $T L E V_{i t}$ ), and therefore, would not require a substantial investment to be used by an investor. The remaining risk proxies would require an investor to be able (and willing) to read a balance sheet statement (e.g., $N A T A_{i t}$ and $\left.P D T A_{i t}\right)$. Such bank-specific risk measures are less likely to trickle into the public domain.

\section{Private Information}

Bank supervisors regularly examine U.S. banking organizations and assign confidential ratings based on these examinations, balance sheet and income statement information, and other publicly available information. Five areas of each banking organization are rated: Bank subsidiaries, other nonbank subsidiaries, Parent company, Earnings and capital adequacy. Therefore, the composite supervisory rating is known by the acronym BOPEC.

Banking organizations with a composite supervisory rating of 1 or 2 are considered the safest and most well-managed institutions by bank supervisors. And, banking organizations with composite supervisory ratings of 3,4 , or 5 have moderate to substantial deficiencies that were uncovered during the examination process. From these ratings we constructed two indicator variables: (1) BOPEC2, equaled one if the composite supervisory rating equaled 2, and zero otherwise; and, (2) BOPEC345, equaled one if the composite supervisory rating equaled 3,4 , or 5 , and zero otherwise.

Supervisory ratings, BOPEC2 and BOPEC345, are the most private information among our explanatory variables. We assume that they are a reasonable statistic for the banks' own knowledge of their riskiness. Although it could be argued that these variables are proprietary information of the bank, Krainer and Lopez (2002) have presented empirical evidence that demonstrates that balance sheet, income statement, and stock price information can be used to predict both supervisory ratings and their changes four quarters prior to their assignment. This finding suggests that these ratings are highly correlated with information that is available to sophisticated investors.

\section{Business and Bond Market Conditions}

We used three quarterly measures of business and bond market conditions, which are publicly available. First, aggregate business conditions

\footnotetext{
${ }^{19}$ Data on the market value of common stock are available on the Center for Research in Security Prices (CRSP) tape that is published by the University of Chicago Graduate School of Business.
} 
were proxied by the unemployment rate $(U E)$. This measure was chosen because it is a lagging indicator of business conditions as are bank lending activities: Both commercial and industrial loans outstanding and the ratio of consumer installment credit to personal income are lagging indicators of business conditions. ${ }^{20}$

Second, the market risk premium was proxied by contemporaneous stock market excess returns $(X R)$. In each quarter, this premium was measured using the quarterly average of daily excess stock returns (calculated as the difference between the daily value-weighted return on NYSE, Amex, and Nasdaq stocks and the off-the-run one month Treasury return).

And third, bond market conditions were proxied by an implied stock volatility measure (MKTVOL). This measure was based on real-time S\&P 100 (OEX) index option bid/ask quotes supplied by the Chicago Board Options Exchange. ${ }^{21}$

\subsection{The empirical model}

\subsubsection{The issuance decision}

We posit that debt issuance decisions depend not only on publicly available risk proxies for each banking organization $\left(N A T A_{i t}, P D T A_{i t}, O R E O_{i t}, A G A P_{i t}\right.$, and, MKTLEV $\left.V_{i t}\right)$, private information $\left(B O P E C 2_{i t}\right.$ and BOPEC345 $\left.5_{i t}\right)$ as well as business and bond market conditions $\left(U E_{t}, X R_{t}\right.$, and $\left.M K T V O L_{t}\right)$, but also on banking organization-specific characteristics such as recent debt issuance activities, bank size, and potential tax benefits. ${ }^{22}$ Recent debt issuance activities were allowed to vary across seniority grades $(g$, where $g=E$ for senior debt and $g=U$ for subordinated debt) for each banking organization. For each seniority grade, we constructed an indicator variable, ISSUE $E_{g, i, t-1}$, that equaled one when the banking organization issued debt grade $g$ in the previous period, and zero otherwise. ${ }^{23}$ And, banking organization size was measured using the natural $\log$ of total assets, $\ln \left(A S S E T_{i t}\right) .{ }^{24}$

Tax shelter benefits for corporate debt imply that a banking organizations' marginal tax rate will influence its choices with respect to debt or equity issuance. As a proxy for the marginal tax rate facing each banking organization, we used its foreign and domestic income taxes as a percentage of net income $\left(A V G T A X_{i t}\right)$. And to account for differences in capital structure across banking organizations, we used the ratio of book equity to book total assets $\left(K / A_{i t}\right)$ in the issuance decision model.

It is also expected that the interaction between banking organization-specific risks and the market risk premium would also influence bond issuance decisions.

\footnotetext{
${ }^{20}$ See The Conference Board, U.S. Composite Indexes.

${ }^{21}$ Implied stock volatility is exogenous to, but highly correlated with, bond market volatility.

${ }^{22}$ To construct the issuance decision variables, ISSUE ${ }_{g, i t}$, the CUSIP Masterfile was used to identify all senior and subordinated debt issues by large U.S. banking organizations. Then, for each debt issue, issuance dates were assigned using Moodys', Fitch, Bloomberg, and Warga databases.

${ }^{23}$ More explicitly, ISSUE $E_{g, i, t-1}$ equals one if banking organization $i$ issued debt type $g$ in either quarter $t-2$, or quarter $t-3$, and zero otherwise.

${ }^{24}$ This proxy will also detect the risk reduction typically achieved by greater diversification at larger firms.
} 
Our issuance decision equations for both senior and subordinated debt are assumed to be linear in all of the variables, or: ${ }^{25}$

$$
\begin{gathered}
I S S U E_{g, i, t}=\beta_{0}+\beta_{1} N A T A_{i t}+\beta_{2} P D T A_{i t}+\beta_{3} O R E O_{i t}+\beta_{4} A G A P_{i t} \\
+\beta_{5} M K T L E V_{i t}+\beta_{6} X R_{t}+\beta_{7} X R_{t} \bullet N A T A_{i t}+\beta_{8} X R_{t} \bullet P D T A_{i t} \\
+\beta_{9} X R_{t} \bullet O R E O_{i t}+\beta_{10} X R_{t} \bullet A G A P_{i t}+\beta_{11} X R_{t} \bullet M K T L E V_{i t} \\
+\beta_{12} B O P E C 2_{i t}+\beta_{13} B O P E C 345_{i t}+\beta_{14} I S S U E_{g, i, t-1} \\
+\beta_{15} \ln \left(A S S E T_{i t}\right)+\beta_{16} A V G T A X_{i t}+\beta_{17} K / A_{i t} \\
+\beta_{18} M K T V O L_{t}+\beta_{19} U E_{t} .
\end{gathered}
$$

These equations were estimated using standard latent variable techniques, which treat the decision to issue as a continuous unobserved variable that represents the probability that a banking organization issues debt type $g$. Each of these probit models was estimated using quarterly data for the largest U.S. banking organizations for the pre-FDICIA period (1985-1992) and for the postFDICIA period (1993-2002).

To ascertain whether parameter estimates were statistically different across the two debt seniority grades in each period, we estimated a "stacked data issuance decision model." That is, we created a combined data set for each banking organization that stacked its subordinated debt data set above its senior debt data set (for each quarter) so that the combined data set could be used to estimate an expanded model. The "stacked data issuance decision model" for each banking organization has as the dependent variable the stacked issuance decision indicator variables for subordinated debt $\left(I S S U E_{U, t}\right)$ and for senior $\operatorname{debt}\left(I S S U E_{E, t}\right)$. The explanatory variables included the original set of explanatory variables (i.e., (NATA, PDTA, OREO, AGAP, and MKTLEV), XR, $(X R \bullet N A T A, X R \bullet P D T A, X R \bullet O R E O, X R \bullet A G A P$, and XR•MKTLEV), (IS$S U E_{g, t-1}$, ln (ASSETS), AVGTAX, K/A, BOPEC2 and BOPEC345), (MK$T V O L$ and $U E)$ ) and each of those explanatory variables interacted with a senior grade indicator variable, $I$, that equaled one when $g$ was senior and zero when $g$ was subordinated. With this specification, the parameter estimates on the interacted explanatory variables were significant only when the individual parameter estimates for the original issuance decision model are statistically different when senior debt market data, rather than subordinated debt market data, are used.

\subsubsection{Issuance spreads}

Issuance spreads are likely to depend on many of the same factors that influence issuance decisions, such as the issuing banking organizations' risk $\left(N A T A_{i t}\right.$, $P_{\text {DTA }}$, OREO $O_{i t}, A G A P_{i t}$, MKTLEV $_{i t}$ BOPEC2 and BOPEC345) the market risk premium $\left(X R_{t}\right)$, bond market conditions $\left(M K T V O L_{t}\right)$, the frequency of debt issuance $\left(I S S U E_{g, i, t-1}\right)$, and bank size $\left(\ln \left(A S S E T_{i t}\right)\right)$. In addition,

\footnotetext{
${ }^{25}$ For continuous right hand side variables, the average value for a two quarter interval was used, and for binary right hand side variables, the average of the appropriate underlying variable over two quarters was used. The left hand side variable was set equal to one if the bank issues in a two quarter period and zero otherwise. To enhance the exogeneity of the right hand side variables, explanatory variables were lagged by one quarter.
} 
observed issuance spreads will likely depend on the instrument characteristics of the bonds that were issued, such as call options, time to maturity, coupon frequency, and the amount issued. ${ }^{26}$ Because callable debt allows a firm to refinance it when the rate becomes lower, we included in our spread model an indicator variable, $C A L L$, that equaled one when an issue had a call option, and that equaled zero otherwise.

To capture non-standard maturity effects on spreads, we used two indicator variables: (1) an indicator variable for bonds issued with a maturity less than 10 years, MATLT10, and (2) an indicator variable for bonds issued with a maturity greater than 20 years, MATGT20. Each of these indicator variables equaled one for the specified maturity range, and zero otherwise.

It seems reasonable that coupon frequency could affect the types of investors willing to purchase an instrument. To capture this potential effect on debt spreads, we included two indicator variables, COUPON12 and COUPON2, that equaled one when the coupon frequency is monthly and semi-annually, respectively, and that equaled zero otherwise.

In addition, issuance spreads may depend on the amount of the debt instruments that was issued. To capture this potential effect, we included the issuance size of the debt instrument (ISSUESIZE).

The issuance spread on each bond was calculated using derived bond yields computed by the Newton-Raphson iterative method from issuance prices and an interpolated Treasury yield of the same maturity. ${ }^{27}$ The term structure of Treasury interest rates was identified on each issuance date by using a smoothing spline of the forward rate curve that incorporated a "roughness" penalty determined by generalized cross validation. This splining technique is described in Fisher, Nychka, and Zervos (1995).

Because issuance spreads are only observed for those banking organizations that actually chose to issue debt, it is important to use a sample selection model to analyze such spreads. We used Heckman's two-stage method to obtain consistent estimates of our sample selection model: This method involved estimating the issuance decision equation described above (estimated with probit), and then using the inverse Mills ratio function of the probit residuals as an extra variable in a regression for the observed issuance spreads.

The regression estimated for observed issuance spreads over Treasury securities with comparable maturities for our two debt seniority grades was:

\footnotetext{
${ }^{26}$ Instrument characteristics for each subordinated and senior bond were identified using Moody's Default Risk Service (DRS) database, Fitch Investment Securities Database, Warga and Bloomberg databases, as well as monthly issues of Mergent Bond Record over the January 1984-December 2002 period, inclusive.

${ }^{27}$ Issuance prices were obtained from various sources including Bloomberg and Moody's DRS. Yields for floating rate bonds are calculated by contract (i.e., a pre-specified number of basis points above the LIBOR rate). The appropriate SWAP rate, from Bloomberg, on the issuance date was used to convert the yield on each floating rate bond to its fixed rate equivalent.
} 


$$
\begin{aligned}
& \text { SPREAD } D_{g, i, t}=\beta_{0}+\beta_{1} N A T A_{i t}+\beta_{2} P D T A_{i t}+\beta_{3} O R E O_{i t}+\beta_{4} A G A P_{i t} \\
& +\beta_{5} M K T L E V_{i t}+\beta_{6} X R_{t}+\beta_{7} X R_{t} \bullet N A T A_{i t} \\
& +\beta_{8} X R_{t} \bullet P D T A_{i t}+\beta_{9} X R_{t} \bullet O R E O_{i t}+\beta_{10} X R_{t} \bullet A G A P_{i t} \\
& +\beta_{11} X R_{t} \bullet M K T L E V_{i t}+\beta_{12} \text { BOPEC } 2_{i t}+\beta_{13} \text { BOPEC } 345_{i t} \\
& +\beta_{14} I S S U E_{g, i, t-1}+\beta_{15} \ln \left(A S S E T_{i t}\right)+\beta_{16} \text { MKTVOL }_{t} \\
& +\beta_{17} C A L L_{i t}+\beta_{18} \text { MATLT } 10_{i t}+\beta_{19} \text { MATGT } 20_{t} \\
& +\beta_{20} \text { COUPON } 12_{i t}+\beta_{21} \text { COUPON } 2_{i t}+\beta_{22} \text { ISSUESIZE } \\
& +\beta_{23} \text { MILLSRATIO }{ }_{i t} \text {. }
\end{aligned}
$$

As was done with the issuance decision model, we estimated a "stacked data sample selection model" to ascertain whether parameter estimates were statistically different across the two debt seniority grades in each period. This stacked model had as its dependent variable the stacked issuance spreads for subordinated debt $\left(S P R E A D_{U, t}\right)$ and for senior debt $\left(S P R E A D_{E, t}\right)$. The explanatory variables included the original set of explanatory variables (i.e., those indicated in equation (25) above) and each of those explanatory variables interacted with a senior grade indicator variable, $I$, that equaled one when $g$ was senior and zero when $g$ was subordinated. With this specification, the parameter estimates on the interacted explanatory variables were significant only when the parameter estimates for the original sample selection model for senior debt were statistically different from those for subordinated debt.

\subsection{Regulatory regimes}

The key determinants of subordinated debt spreads - bank failure probabilities and senior debt recovery rates - are heavily influenced by regulatory regimes. The most relevant changes within our sample period are the introduction of the Federal Deposit Insurance Corporation Improvement Act (FDICIA) in 1991, shortly followed by the enactment of depositor preference in 1993. To account for this regulatory reform, we split our sample accordingly and refer to the two subperiods as the pre-FDICIA (1985-1992) and post-FDICIA (1993-2002) periods.

Bank failure rates in the pre-FDICIA period were generally higher than in the post-FDICIA period. This is likely due to less favorable business conditions or to less timely corrective action by bank supervisors. Given a bank failure, investors expected lower relative losses in this period due to frequent resolutions through purchase-and-assumption. Thus, reported recovery rates of about 25 percent for senior debt in this period may somewhat underestimate true recovery rates inclusive of purchase and assumption resolutions.

The post-FDICIA period is characterized by prompt corrective action (PCA), ${ }^{28}$ higher barriers against bank bailouts, and depositor preference. These regulatory changes have different impacts on the variables of our model. Default frequencies most likely have been reduced by PCA and the resulting regulatory pressure on banks to raise capital before they become insolvent. The impact on recovery rates, once default does occur, is less favorable for investors. Under depositor preference, depositors (including the FDIC in receivership) are given a priority claim on a failing bank's assets. The holders of non-deposit liabilities

\footnotetext{
${ }^{28}$ The capital-based policy of prompt corrective action began in December 1992.
} 
only share what remains once depositor claims are paid off. Most of all, senior investors seem to be worse off in a bank failure than they they were prior to the implementation of depositor preference. Subordinated investors have a weaker claim as well, but they could not expect to get much even before the implementation of depositor preference. With respect to risk characteristics, senior debt thus is similar to subordinated debt in the post-FDICIA period. ${ }^{29}$

\subsection{Hypotheses}

\subsubsection{The issuance decision}

\section{Expected Signs of the Parameter Estimates:}

Although the magnitude of parameter estimates may vary across the regulatory regimes, the expected signs of parameters in our issuance decision model are generally the same for both senior and subordinated debt. The expected signs of parameters for publicly available risk measures $\left(N A T A_{i t}, P D T A_{i t}, O R E O_{i t}\right.$, $A G A P_{i t}$, and, $\left.M K T L E V_{i t}\right)$ are negative because each of these measures reflect greater risk and/or a deteriorating financial condition for the banking organization.

The expected sign of the parameters for stock market excess returns $(X R)$ is negative because this measure rises when the market premium for risk rises. Moreover, the expected signs of parameters for risk measures interacted with stock market excess returns $(X R \bullet N A T A, X R \bullet P D T A, X R \bullet O R E O, X R \bullet A G A P$, and $X R \bullet M K T L E V)$ are negative since a banking organization experiencing financial distress may be much less likely to issue debt in a period when the market risk premium is high compared to when this premium is lower.

In contrast, the expected signs of parameters for banking organizationspecific factors $\left(\left(I S S U E_{g, i, t-1}\right), \ln \left(A S S E T_{i t}\right), A V G T A X_{i t}, K / A_{i t}, B O P E C \mathscr{2}_{i t}\right.$ and $\left.B O P E C 345_{i t}\right)$ are positive. It is conventional wisdom that issuance costs are lower for firms that frequently issue debt. ${ }^{30}$ In addition, issuance costs may be lower for larger firms because major debt market investors typically specialize in gathering information on a small number of firms. ${ }^{31}$ Holding a banking organization's capital structure (i.e., $K / A_{i t}$ ) constant, the higher its tax rate, the more it benefits from being able to deduct the interest payments paid to bondholders. At the same time, the less leveraged the firm is, the more likely it can issue debt, so bond issuance activities would be positively correlated with $K / A_{i t}$. Regardless of the potential tax benefits derived from debt issuance, bank supervisors may pressure a banking organizations' management to raise regulatory capital. U.S. banking organizations are subject to Capital Adequacy Guidelines that allow some debt instruments (e.g., mandatory convertible debt securities and term subordinated debt) to be included in supplementary capital (i.e., tier 2 capital). This means that not all debt instruments are equal from a supervisory perspective when a banking organization is under duress. Moreover, core capital elements (e.g., common stockholders equity) are preferred to any debt instrument in such circumstances. We would expect that banking

\footnotetext{
${ }^{29}$ We neglect that expected recovery rates on senior debt also depend on the fraction of subordinated and of senior debt to total liabilities as well as on the expected shortfall of assets with respect to liabilities.

${ }^{30}$ See Board of Governors of the Federal Reserve System (1999, p. 46. )

${ }^{31}$ See Board of Governors of the Federal Reserve System (1999, p. 47.)
} 
organizations with a composite supervisory rating of 1 would be least likely to be under some pressure to improve their total regulatory capital.

And the expected signs of parameters for bond market conditions and macroeconomic conditions $\left(M K T V O L_{t}\right.$ and $\left.U E_{t}\right)$ are negative. This is because bond market liquidity premiums tend to rise correspondingly with $M K T V O L_{t}$ and because bank lending activities are highly correlated with lagging indicators, such as unemployment.

\section{The Pre-FDICIA Period:}

Our "informed investor model" would imply that the bank borrows from uninformed investors (i.e., issues senior debt) when there is bad news with respect to the financial prospects of the firm. This suggests that the parameter estimates for accounting- and market-based risk variables would jointly be positive in the issuance decision model for senior debt.

In contrast, our model would imply that the bank borrows from informed investors (i.e., issues subordinated debt) when there is good news with respect to the financial prospects of the banking organization. This suggests that the parameter estimates for accounting- and market-based risk variables would jointly be negative in the issuance decision model for subordinated debt. Moreover, in such circumstances the banking organization would not borrow from uninformed investors, i.e., it would not issue senior debt.

We thus postulate that subordinated debt would be issued in times when private information contains good news, and senior debt would be issued in times when private information contains bad news. If this is true, of course, the rival model where subordinated debt is issued when a bank has adverse private information (Barclay and Smith, 1995) is not plausible.

\section{The Post-FDICIA Period:}

In principle, prompt corrective action would reduce the frequency of bank defaults. Consequently, we would expect issuance decisions for both subordinated and senior debt to be less risk sensitive in the post-FDICIA period compared to the pre-FDICIA period. At the same time depositor preference lowered the liquidation standing of senior creditors and made it more likely that such investors would incur losses in the event of a bank failure. In this case, we would expect that the risk sensitivity of issuance decisions would become similar for senior and subordinated debt.

\subsubsection{Issuance spreads}

\section{Expected Signs for the Parameter Estimates}

In the issuance spread regression, parameter estimates on banking organizationspecific risk proxies are expected to be generally positive. Even uninformed investors should respond to risk proxies that are widely accessible and readily attainable (e.g., OREO $O_{i t}$ and $M K T L E V_{i t}$ ). Thus, such risk proxies are expected to be positively correlated with observed issuance spreads, regardless of the seniority of the debt instrument issued. In contrast, only informed investors should respond to risk proxies that are more private in nature (e.g., $B O P E C 2_{i t}$ and BOPEC345 ${ }_{i t}$ ). Such risk proxies are expected to be positively correlated with observed subordinated debt spreads, but not to influence senior debt spreads. 
The market price of risk is expected to be positively correlated with banking organizaton debt spreads. If senior debt market investors are not risk averse, then we would expect the parameter on the market price of risk to be insignificant. But, if these investors are risk averse, the market price of risk parameter would be positive and significantly influence both senior and subordinated spreads. Similarly, investor risk aversion would influence the significance of the bank-specific risk measures interacted with the market price of risk. Positive parameters on these variables - separately or together as a group - would imply that issuance spreads were relatively higher for riskier banking organizations in periods when the market price of risk was high.

Frequent issuers and larger banking organizations are expected to have lower issuance spreads than other banking organizations, holding all else constant. This is because investors typically follow only a handful of firms and they prefer to hold issues that are relatively liquid. Larger firms are able to issue debt in larger issue sizes more frequently, and thus their debt issues tend to be quite liquid.

Spreads tend to increase in periods when bond market volatility rises. ${ }^{32}$ It is therefore expected that the parameter estimate for $M K T V O L_{t}$ in the spread regression would be positive.

In addition, the observed issuance spreads for both senior and subordinated debt issues are expected to be influenced by the characteristics of the individual instruments that are issued. First, consider a firm that issues two instruments simultaneously where one has a call option and the other does not. The instrument with the call option would be expected to have a larger spread than the one that does not. Thus, it is expected that the sign on CALL would be positive. ${ }^{33}$

It may be the case that bonds with non-standard maturities are less liquid than those with standard maturities. ${ }^{34}$ This would suggest that the parameter estimates of the indicator variables for maturities less than 10 years (MATLT10) and for maturities greater than 20 years (MATGT20) would be expected to be positive.

In contrast, smaller issues tend to rapidly get absorbed into investor portfolios, such issues tend to be less liquid in the secondary market. ${ }^{35}$ For this reason, smaller issues are more difficult and expensive to sell to institutional investors. ${ }^{36}$ Therefore, it is expected that issuance spreads are likely to be negatively correlated with issuance size (ISSUESIZE).

\footnotetext{
${ }^{32}$ See Covitz, Hancock, and Kwast, 2001.

${ }^{33} \mathrm{~A}$ negative or zero coefficient on the call option indicator variable would imply that debt holders did not value the call option appropriately.

${ }^{34}$ Non-standard maturity instruments may be issued by banking organizations to match the duration of their liabilities with the duration of their assets, or these instruments may be issued when an organization wants to attract funds from small retail investors.

${ }^{35}$ Hancock and Kwast (2001) present histograms of weekly subordinated debt spread discrepancies between Bloomberg and Interactive Data Corporation pricing data sources over the January 1997 to October 1999 period for bonds stratified by issuance size. The tightest distribution of spread discrepancies is for bonds with issuance sizes greater than $\$ 300$ million. The next tightest distribution was for bonds with issuance sizes between $\$ 100$ million and $\$ 300$ million. And, the widest distribution was for bonds with issuance sizes less than $\$ 100$ million. The decreased dispersion in spread discrepancies for larger issues suggests that there may be a positive correlation between the flow of trade in a particular bond and its amount outstanding at issuance.

${ }^{36}$ See Board of Governors of the Federal Reserve System (1999, p. 46.)
} 
It seems reasonable that higher coupon frequencies (e.g., monthly payments) would attract smaller "retail" investers, and the resulting higher demand would lower the issuance spread. Therefore, the expected sign for the parameter estimate of the monthly coupon payment indicator (COUPON12) would be negative.

\section{The Pre-FDICIA Period:}

Depositor preference rules were not taken for granted in this period, so senior debt holders are distinct from subordinated debt holders. In this case, we would expect senior debt holders to focus on the publicly available and easily accessible information. This is because senior debt holders have less of an incentive to become informed when they are likely to rank with (uninsured) depositors in this period. Senior spreads would also react to the market price of risk if senior investors are risk averse. If a difference in investors' beliefs, not risk aversion, is the main reason why banks issue dual class debt, we would expect no significant influence of the market price of risk on spreads.

Subordinated debt spreads, would also be sensitive to proxies of public risk (including the market price of risk if senior investors are risk averse), as has been shown in our model. ${ }^{37}$ At the same time, subordinated debt holders would, of course, focus on their private risk proxies that are quite costly for them to obtain. In their view, observed subordinated debt spreads would be unduly influenced by the publicly available information and not fully reflect their own private information. This suggests that the parameter estimates on the interacted public risk variables with the senior indicator in the stacked spread regression would not be significantly different from zero. But, the parameter estimates on the private risk variables would only be significant for subordinated debt spreads, since these instruments are purchased by sophisticated investors. In the spread regression for senior debt spreads, we would expect the parameter estimates on the private risk variables to not be statistically significant from zero.

Our model also suggests that spreads are more sensitive to risk measures when both publicly and privately perceived risks are relatively high and when both increase at the same time. In terms of the spread regression, we would expect significant effects for the banking organization-specific risk proxies interacted with the market price of risk.

The Post-FDICIA Period:

After depositor preference legislation, all public debt holders are subordinated to depositors, even those that are "senior" debt holders. Depositor preference rules are thus expected to lower the recovery rate on senior debt in this period. This impact of depositor preference would likely increase the incentive premium contained in subordinated debt spreads. Hence, such spreads would be more sensitive to the information used by senior investors, i.e., to publicly available and accessible information on banking organization risk, and less sensitive to private information gathered by informed investors.

At the same time, the premium between subordinated and senior debt would become small as these instruments become more similar in their standing. We would expect differences in risk sensitivity between senior and subordinated debt to be lower in this period.

\footnotetext{
${ }^{37}$ Given pre-FDICIA recovery rates on senior debt of around 25 percent, we would expect the subordinated debt spread to be quite sensitive to publicly perceived bank risk.
} 
These expectations are derived under the assumption that senior depositors still rely on the same kind of public information in this period. In a longer-term perspective though, one should expect senior investors to become aware of the weaker standing of their claims under depositor preference. This might give these investors a stronger incentive to collect more private information on the quality of banking organizations. Both, senior and the subordinated spreads, would thus become less responsive to public information and more responsive to private information. Investors who do not find it worthwhile to collect private information would likely replace senior debt in their portfolio by instruments with higher rank in case of a bank failure such as certificates of deposit.

\subsection{Findings}

\subsubsection{Trends in the data and distributions of spreads}

Before turning to our parameter estimates, it is instructive to take a brief look at the bond market data for large U.S. banking organizations over the 1985 to 2002 period, inclusive. First, it is readily apparent that the number of large banking organizations that issue senior and subordinated debt instruments varies considerably across time (Figure 3.1). Interestingly, it appears that fewer banking organizations issue senior debt during periods when more banking organizations issue subordinated debt.

The number of public debt issues made by large U.S. banking organizations increased dramatically in the mid-1990s (Figure 3.2). In the late 1980s, it was not uncommon for such organizations to collectively issue less than 20 debt instruments in a year of each of the seniority grades. But, by the late 1990s, there were several years in which large U.S. banking organizations collectively issued more than 100 instruments in each seniority grade.

With the increase in the number of debt issues made by large U.S. banking organizations per annum, there was less standardization in the contract terms for both subordinated and senior bonds. Table 3.1 presents information on selected contract terms and the number of subordinated instruments issued for each year over the 1985-2002 period. In the mid-1980s, subordinated instruments typically were issued with a maturity in the 10 to 20 year range, with no call option, with semi-annual coupon payments, and with a fixed rate of interest. By the late-1990s, however, a higher proportion of subordinated instruments were issued with maturities less than 10 years, with call options, with a floating rate, and with coupons that were paid either monthly or quarterly. Similar patterns emerge from consideration of the information contained in the Table 3.2. Compared to the recent past, senior debt instruments issued by large banking organizations in the early years of the sample period were less likely to have a maturity of less than 10 years, and more likely to pay coupons semiannually at a fixed rate of interest. A comparison of Tables 3.1 and 3.2 suggests that subordinated instruments tend to have longer maturities than those of senior instruments, and that floating rate contracts are more prevalent near the end of the sample period for both seniority grades.

Figure 3.3 contains box plots of observed issuance spreads for bonds in each seniority grade for each year in the 1985:Q1 to 2002:Q4 period. These box plots are graphical representations of the center and width of spread distributions along with outliers. The height of each box is equal to the interquartile width, 


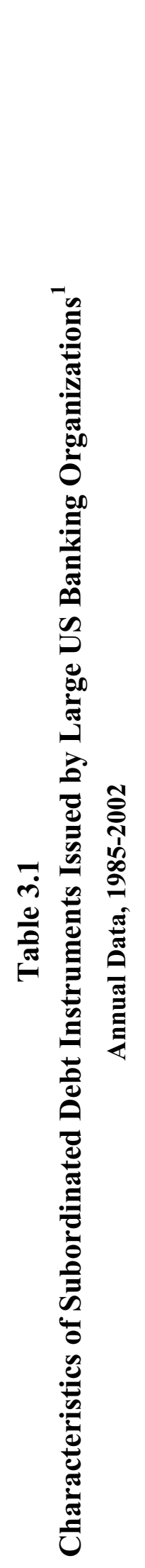

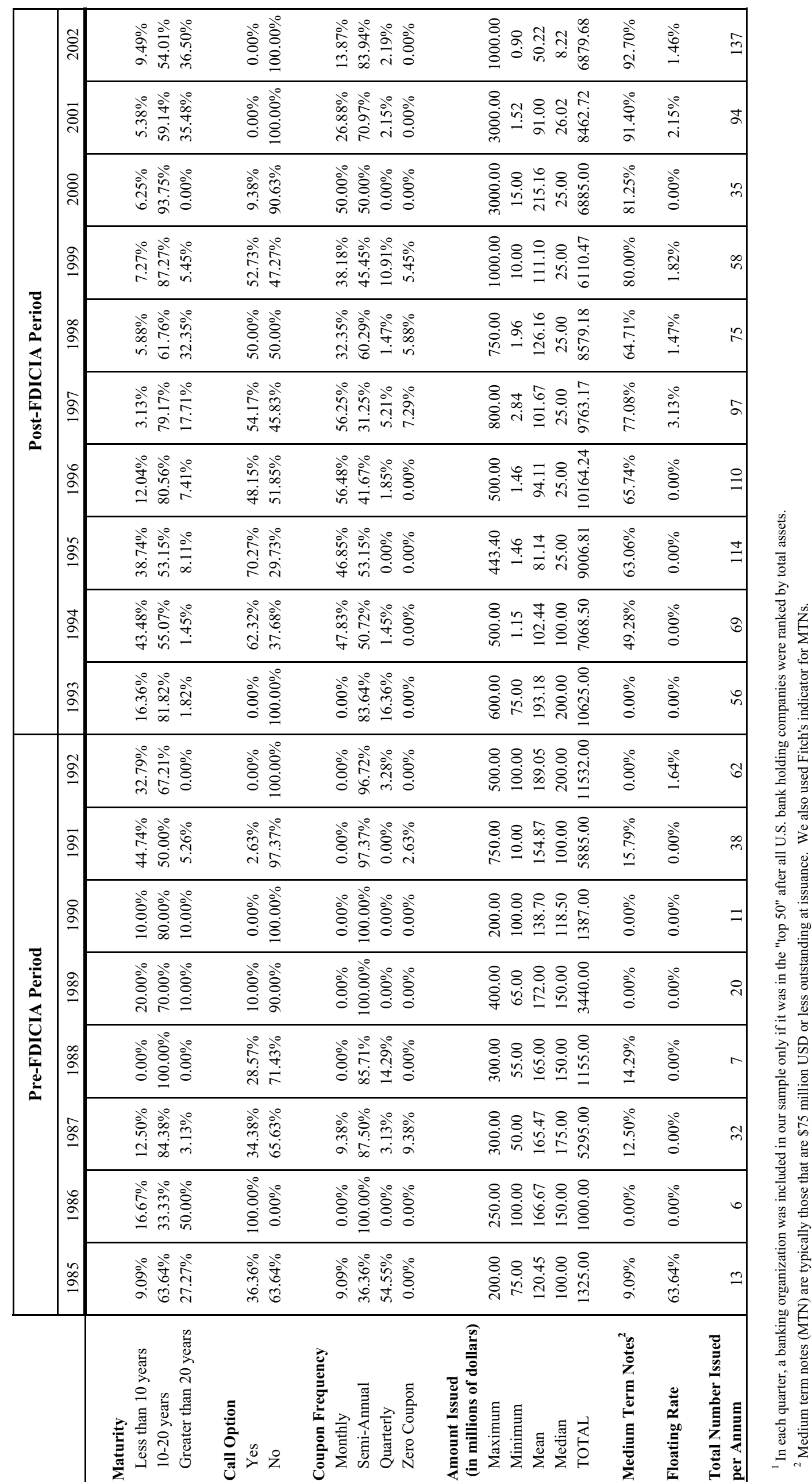




\begin{tabular}{|c|c|c|c|c|c|c|c|c|c|c|}
\hline & & ఫ్స & 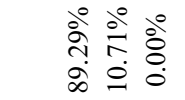 & 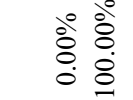 & 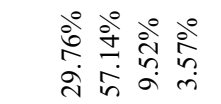 & 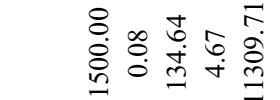 & $\stackrel{\text { ֻें }}{\stackrel{\sim}{*}}$ & 总 & \pm & \\
\hline & & ఫे & 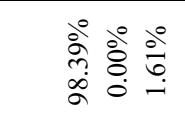 & $\begin{array}{l}00 \\
\vdots \\
0 \\
0 \\
0\end{array}$ & 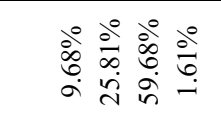 & 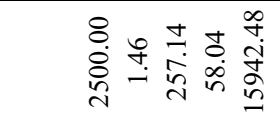 & $\begin{array}{l}\stackrel{\circ}{\circ} \\
\dot{0} \\
\dot{b} \\
\dot{b}\end{array}$ & $\begin{array}{l}\text { خें } \\
\text { ते } \\
\text { वे }\end{array}$ & $\mathcal{S}$ & \\
\hline & & ڤे & 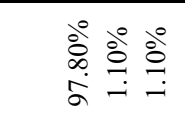 & 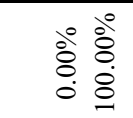 & 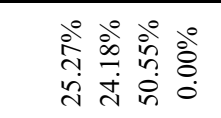 & 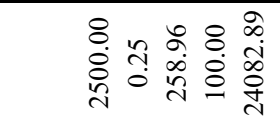 & 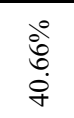 & 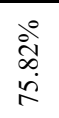 & \pm & \\
\hline & & Әे & 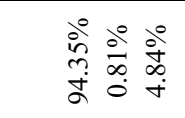 & 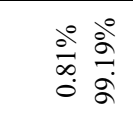 & 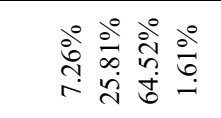 & 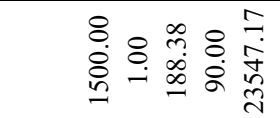 & $\frac{\stackrel{\circ}{\circ}}{\vec{g}}$ & 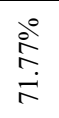 & $\stackrel{\Xi}{I}$ & \\
\hline . & 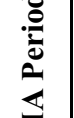 & $\begin{array}{l}\infty \\
\stackrel{2}{\sigma}\end{array}$ & 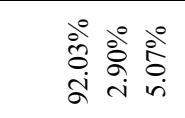 & 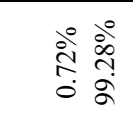 & 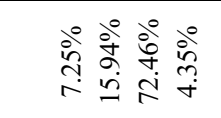 & 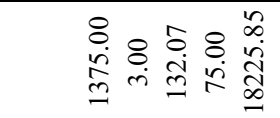 & 峁 & 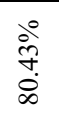 & $\begin{array}{l}\infty \\
\cong\end{array}$ & \\
\hline 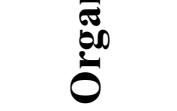 & 竞 & $\hat{\sigma}$ & 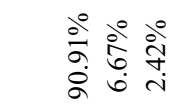 & 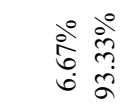 & 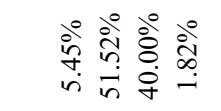 & 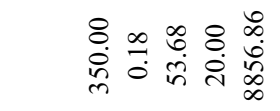 & 总 & 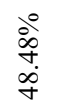 & 5 & \\
\hline$\stackrel{00}{\Xi}$ & & $\begin{array}{l}\circ \\
\approx\end{array}$ & 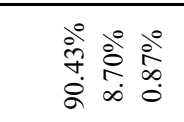 & 官命 & 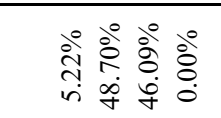 & 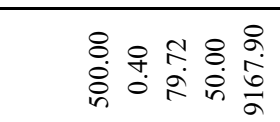 & 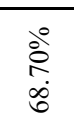 & 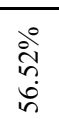 & $\stackrel{\infty}{=}$ & \\
\hline$\frac{\infty}{\infty}$ & & $\stackrel{2}{2}$ & 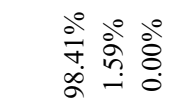 & 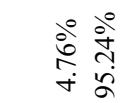 & 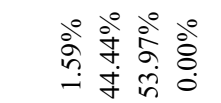 & 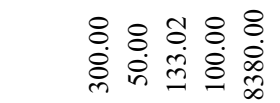 & 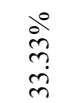 & $\underset{i}{\stackrel{d}{\vec{i}}}$ & $t$ & 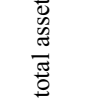 \\
\hline 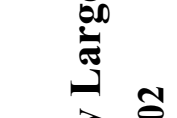 & & $\begin{array}{l}\Delta \\
\stackrel{2}{2}\end{array}$ & 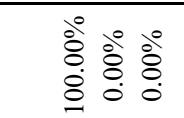 & 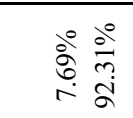 & 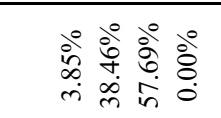 & 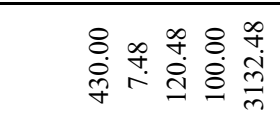 & 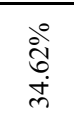 & 它 & $\vec{m}$ & 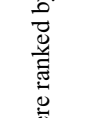 \\
\hline 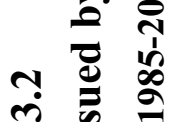 & & ฉ & 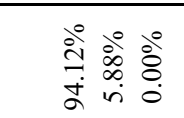 & 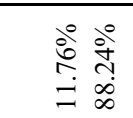 & 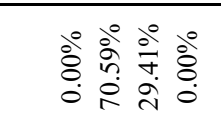 & 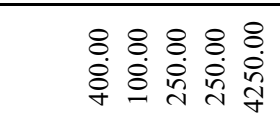 & ठें & $\begin{array}{l}\stackrel{\circ}{7} \\
\stackrel{4}{+}\end{array}$ & $\stackrel{\infty}{\sim}$ & $\frac{1}{2}$ \\
\hline 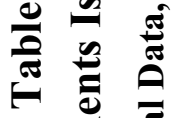 & & 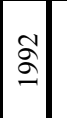 & 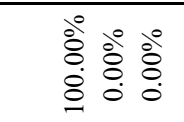 & 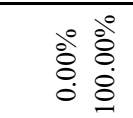 & 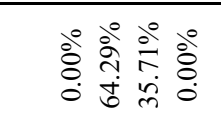 & 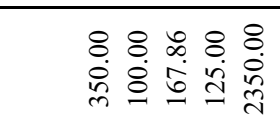 & ठें & 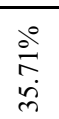 & - & 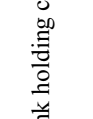 \\
\hline$\stackrel{\Xi}{E}$ & & $\bar{\sigma}$ & $\begin{array}{l}\text { 高 } \\
\dot{0} \\
\dot{0} \\
0 \\
0\end{array}$ & 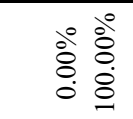 & 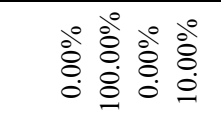 & 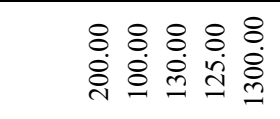 & ठั & 官 & 의 & $\underbrace{\infty}_{=}$ \\
\hline है & & $\stackrel{2}{2}$ & 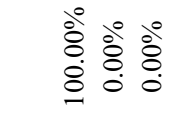 & $\begin{array}{l}00 \\
\dot{8} \\
\dot{0} \\
\dot{0}\end{array}$ & 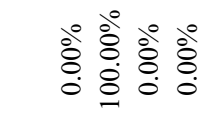 & 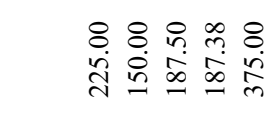 & ठें & छे & $\sim$ & 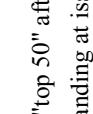 \\
\hline •ֶ气 & 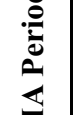 & $\stackrel{\grave{\partial}}{=}$ & 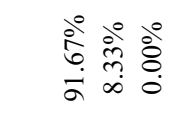 & 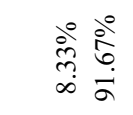 & 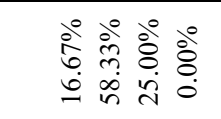 & 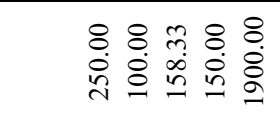 & @ั & $\begin{array}{l}\partial^{\circ} \\
\vdots \\
\dot{q} \\
\dot{y}\end{array}$ & \pm & 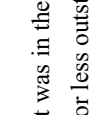 \\
\hline 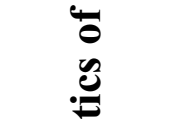 & 定 & $\begin{array}{l}\infty \\
\stackrel{\infty}{=}\end{array}$ & 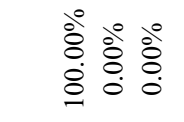 & $\begin{array}{l}0.0 \\
\vdots \\
0 \\
0 \\
0\end{array}$ & 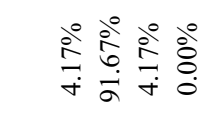 & 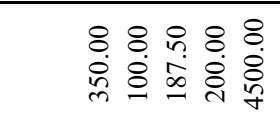 & ळें & 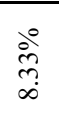 & $\stackrel{\sim}{\sim}$ & 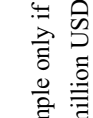 \\
\hline 产 & & \begin{tabular}{l}
$r$ \\
$\infty$ \\
\hdashline \\
\hdashline
\end{tabular} & 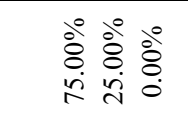 & 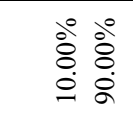 & $\begin{array}{l}\circ 0 \\
8 \\
8\end{array}$ & 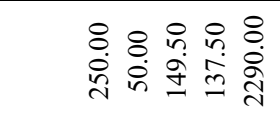 & 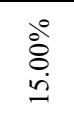 & छें & ป & \\
\hline Е & & $\begin{array}{l}\circ \\
\stackrel{2}{二}\end{array}$ & 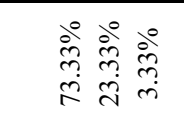 & 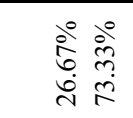 & 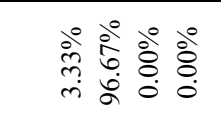 & 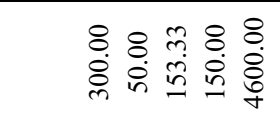 & 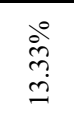 & ळें & $q$ & \\
\hline & & $\begin{array}{l}\infty \\
\infty \\
\approx\end{array}$ & 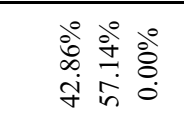 & 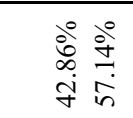 & 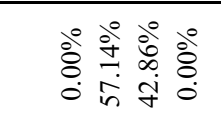 & 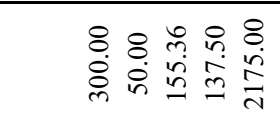 & 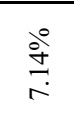 & 高 & ते & \\
\hline & & & 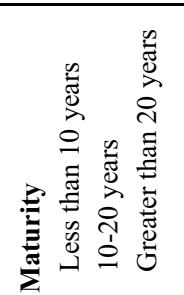 & 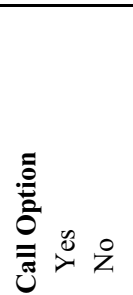 & 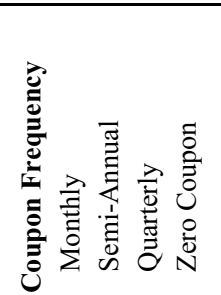 & 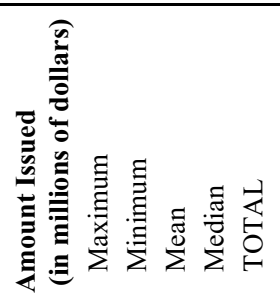 & 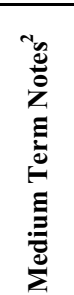 & 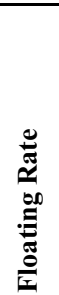 & 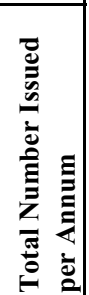 & 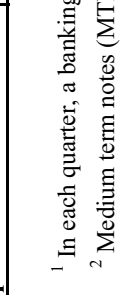 \\
\hline
\end{tabular}


Figure 3.1

The Number of Large US Banking Organizations that Issued Senior and Subordinated Debt

Number of

Banking Organizations

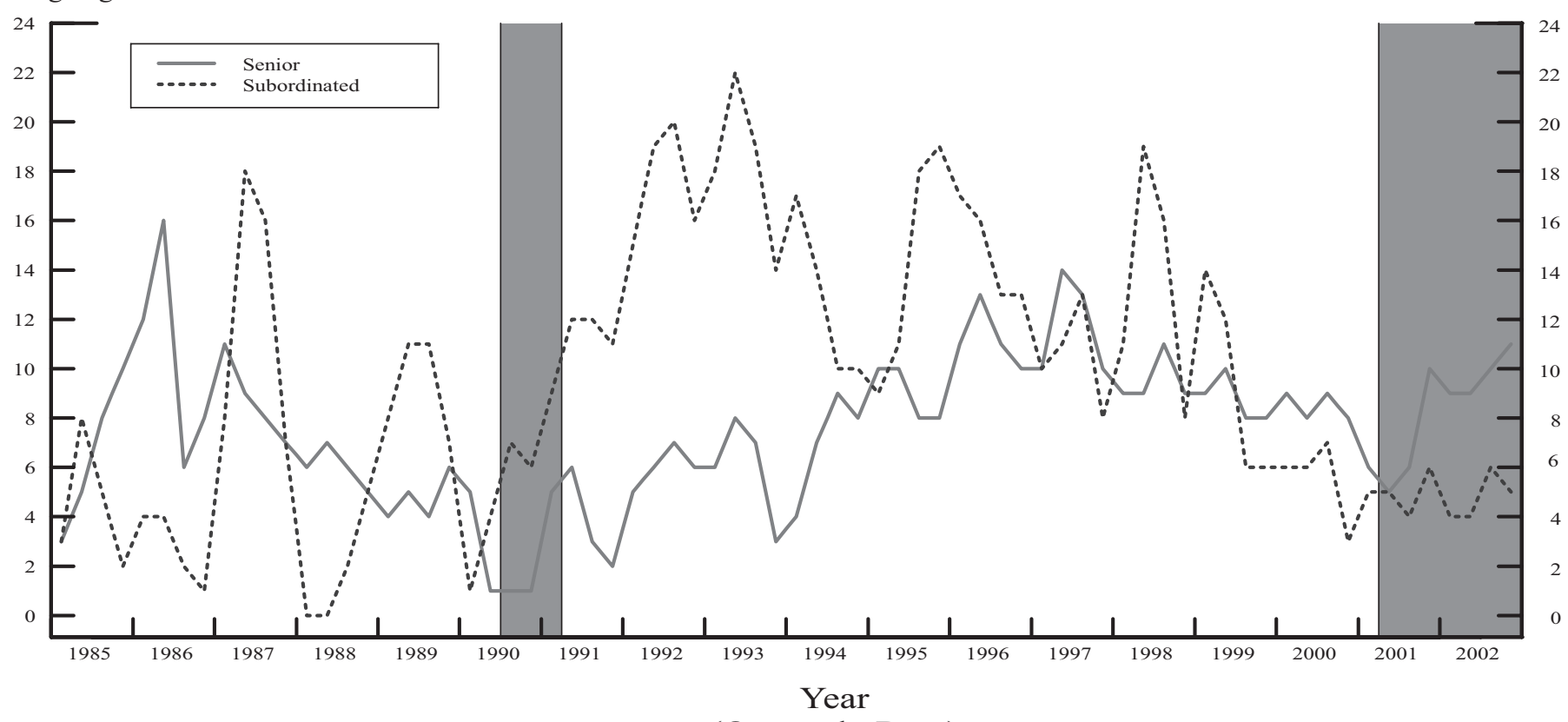

(Quarterly Data)

Figure 3.2

The Number of Senior and Subordinated Debt Instruments that were Issued by Large U.S. Banking Organizations

Number of Issues

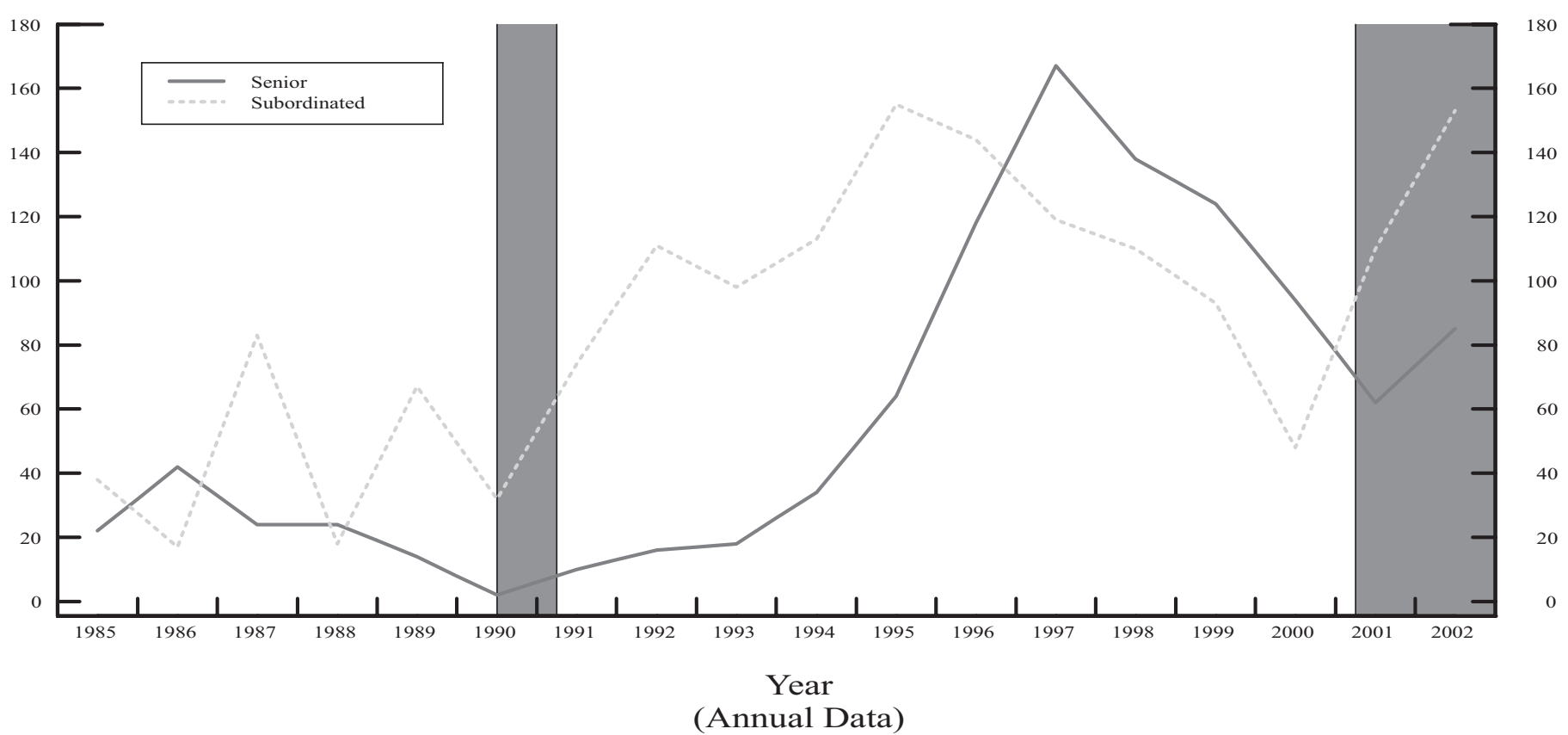

Business cycle peaks and troughs as identified by the National Bureau of Economic Research are indicated by shading. 


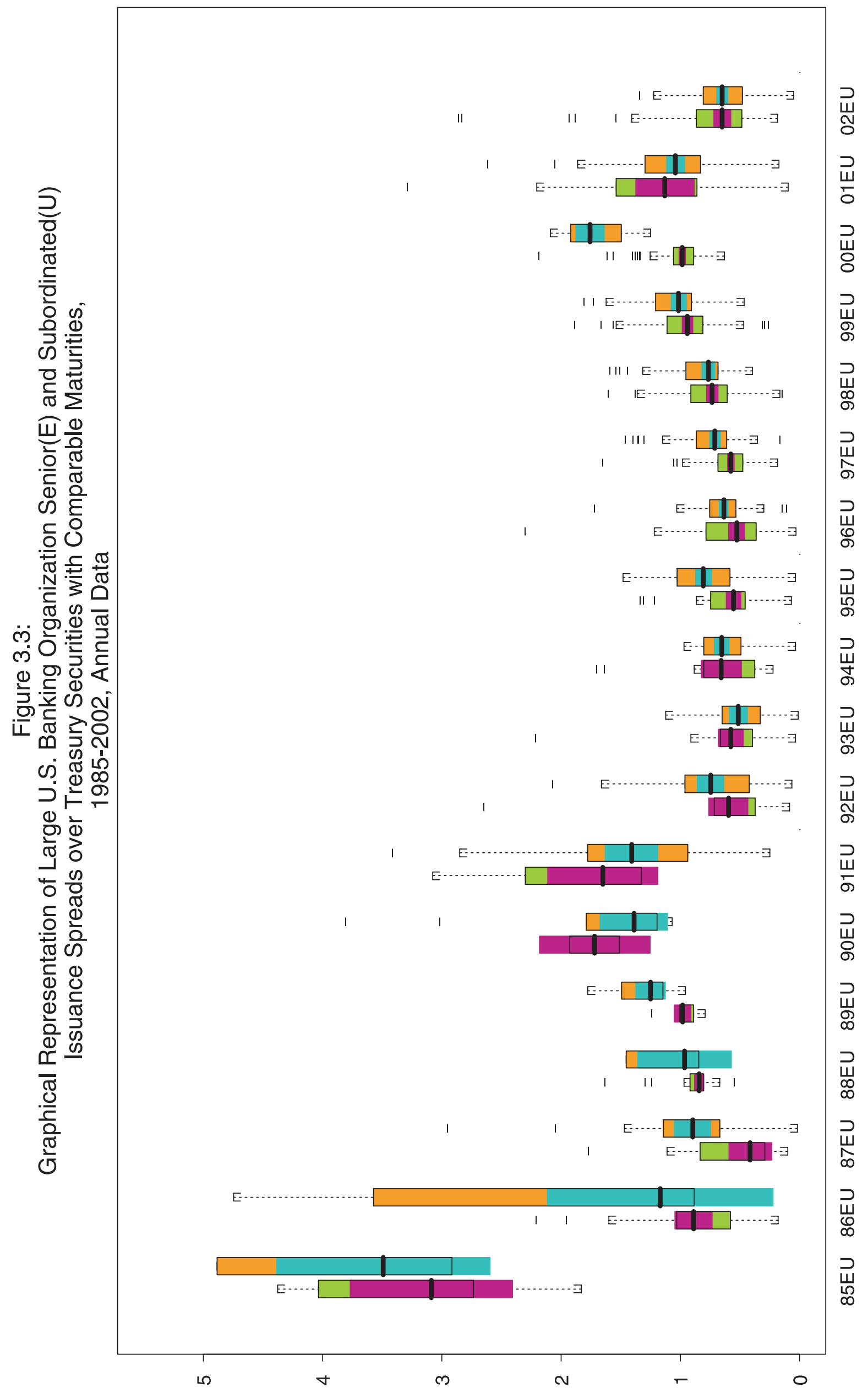


which is the difference between the third quartile and the first quartile of the data. This width widened in the period prior to 1992 for both senior and subordinated debt spreads and then narrowed considerably when the financial condition of large U.S. banking organizations improved. Indeed, in the middle to late 1990s the top quartiles for senior and for subordinated issuance spreads are below the medians for such spreads (which are represented by bold horizontal lines in the interior of each box) that were observed in 1991. The brackets ([ ]) for each box plot are located at extreme values of the data for the year or at a distance equal to 1.5 times the interquartile distance from the center, whichever is less. ${ }^{38}$ In most years, the top bracket for subordinated issuance spreads is higher than the corresponding top bracket for senior issuance spreads with exceptions occurring in 1990, 1991, 1996, 1998, 2001 and 2002. Throughout the 1992 to 1999 period, these upper brackets remained considerably below the medians for senior and subordinated issuance spreads observed in 1991.

\subsubsection{The issuance decision}

The issuance decision model was estimated using quarterly data for the preFDICIA (1985:Q1-1992:Q4) and post-FDICIA (1993:Q1-2002:Q4) periods. Table 3.3 presents parameter estimates for the issuance decision probit models for subordinated and senior debt, equation (24). Dependent variables for the separate probit models are the issuance decision indicator variables for subordinated and senior debt, respectively. The left column of the table provides a short description for each of the explanatory variables. The left panel of the table presents estimates for the issuance decision model for subordinated debt during each of the time periods considered, and the right panel of the table presents estimates for the issuance decision model for senior debt during each of the time periods considered. And, Table 3.4 presents parameter estimates for the stacked data issuance decision model, where the dependent variable for the stacked data issuance decision model is the stacked issuance decision indicator variables for subordinated $\left(I S S U E_{U, t}\right)$ and for senior debt $\left(I S S U E_{E, t}\right)$. Parameter estimates for the explanatory variables interacted with a senior grade indicator variable, $I$, in Table 3.4 are significant only when the individual parameter estimates for the original issuance decision models (in Table 3.3) are statistically different when senior debt market data, rather than subordinated debt market data, are used. Thus, parameter estimates in the stacked regression can be used to infer a "direct effect" for subordianted debt (left panel) and an "additional effect" for senior debt (right panel) in each deposit insurance regime.

Interestingly, there are some banking organization- or issue- specific factors that influence the probability of issuance independently of the type of instrument or the period considered. For example, $\ln (A S S E T S)$ and $I S S U E_{-1}$ are always positive. This means that relatively large banking organizations among the 50 largest, and organizations that have issued in the past six months, are more likely to issue debt. In addition, $K A$ is always negative for subordinated debt, and in the pre-FDICIA period for senior debt (though not significant). This suggests, albeit in the weakest manner, that higher capitalized banking organizations are

\footnotetext{
${ }^{38}$ For data having a Gaussian distribution, approximately 99.3 percent of the data fall inside the brackets. Horizontal dashes represent "unusually deviant data points" that are further than 1.5 times the interquartile distance from the center of the box.
} 
Table 3.3

Parameter Estimates for the Issuance Decision Model of Large U.S. Banking Organizations

\begin{tabular}{|c|c|c|c|c|c|c|c|c|}
\hline \multirow{3}{*}{ Explanatory Variables } & \multicolumn{8}{|c|}{ Dependent Variable / Deposit Insurance Regime } \\
\hline & \multicolumn{4}{|c|}{ Subordinated Issuance } & \multicolumn{4}{|c|}{ Senior Issuance } \\
\hline & $\begin{array}{l}\text { Pre-FDICIA } \\
\text { 85:Q1-92:04 } \\
\end{array}$ & $\begin{array}{c}\text { Expected } \\
\text { Sign? }\end{array}$ & $\begin{array}{l}\text { Post-FDICIA } \\
\text { 93:Q1-02:Q4 } \\
\end{array}$ & $\begin{array}{c}\text { Expected } \\
\text { Sign? }\end{array}$ & $\begin{array}{c}\text { Pre-FDICIA } \\
\text { 85:Q1-92:04 } \\
\end{array}$ & $\begin{array}{c}\text { Expected } \\
\text { Sign? }\end{array}$ & $\begin{array}{l}\text { Post-FDICIA } \\
\text { 93:Q1-02:Q4 } \\
\end{array}$ & $\begin{array}{c}\text { Expected } \\
\text { Sign? } \\
\end{array}$ \\
\hline $\begin{array}{l}\text { Accounting- and Market- based } \\
\text { Risk Measures }\end{array}$ & & & & & & & & \\
\hline $\begin{array}{l}\text { The ratio of non-accruing loans to total assets } \\
\text { (NATA) }\end{array}$ & $\begin{array}{l}-4.389 \\
(-0.69)\end{array}$ & $x$ & $\begin{array}{r}-15.983 \\
(-1.23)\end{array}$ & $x$ & $\begin{array}{r}-21.964 \\
(-2.95)\end{array}$ & $x$ & $\begin{array}{r}24.391 \\
(1.98)\end{array}$ & \\
\hline $\begin{array}{l}\text { The ratio of accruing loans past due } 90 \text { days of } \\
\text { more to total assets (PDTA) }\end{array}$ & $\begin{array}{r}-40.005 \\
(-1.47)\end{array}$ & $x$ & $\begin{array}{l}6.576 \\
(0.25)\end{array}$ & & $\begin{array}{c}53.655 \\
(2.04)\end{array}$ & & $\begin{array}{c}-18.278 \\
(-0.68)\end{array}$ & $x$ \\
\hline $\begin{array}{l}\text { The ratio of other real estate owned to total } \\
\text { assets (OREO) }\end{array}$ & $\begin{array}{l}1.700 \\
(0.12)\end{array}$ & & $\begin{array}{c}27.098 \\
(0.94)\end{array}$ & & $\begin{array}{r}-10.454 \\
(-0.61)\end{array}$ & $x$ & $\begin{array}{r}-48.539 \\
(-1.58)\end{array}$ & $x$ \\
\hline $\begin{array}{l}\text { The absolute value of the difference between } \\
\text { assets and liabilities maturing or repricing } \\
\text { within one year as a proportion of equity value } \\
\text { (AGAP) }\end{array}$ & $\begin{array}{r}-0.0001 \\
(-0.04)\end{array}$ & $x$ & $\begin{array}{l}-0.035 \\
(-1.31)\end{array}$ & $x$ & $\begin{array}{l}0.004 \\
(0.72)\end{array}$ & & $\begin{array}{l}-0.030 \\
(-0.94)\end{array}$ & $x$ \\
\hline $\begin{array}{l}\text { The ratio of total book liabilities to the sum of } \\
\text { the market value of common stock and the book } \\
\text { value of preferred stock (MKTLEV) }\end{array}$ & $\begin{array}{c}-0.0005 \\
(-0.03)\end{array}$ & $x$ & $\begin{array}{l}0.023 \\
(0.82)\end{array}$ & & $\begin{array}{l}-0.029 \\
(-2.33)\end{array}$ & $x$ & $\begin{array}{l}-0.021 \\
(-0.66)\end{array}$ & $x$ \\
\hline $\begin{array}{c}\text { Bank-Specific Risk Measures Interacted } \\
\text { with the Stock Market Excess Returns }\end{array}$ & & & & & & & & \\
\hline $\begin{array}{l}\text { The ratio of non-accruing loans to total assets } \\
\text { interacted with the stock market excess return } \\
\text { (NATA_M) }\end{array}$ & $\begin{array}{l}-0.785 \\
(-1.30)\end{array}$ & $x$ & $\begin{array}{l}-0.081 \\
(-0.03)\end{array}$ & $\mathrm{x}$ & $\begin{array}{l}-0.521 \\
(-0.70)\end{array}$ & $x$ & $\begin{array}{l}1.047 \\
(0.46)\end{array}$ & \\
\hline $\begin{array}{l}\text { The ratio of accruing loans past due } 90 \text { days of } \\
\text { more to total assets interacted with the stock } \\
\text { market excess return (PDTA_M) }\end{array}$ & $\begin{array}{l}6.995 \\
(2.20)\end{array}$ & & $\begin{array}{l}-1.136 \\
(-0.26)\end{array}$ & $\mathrm{x}$ & $\begin{array}{l}-0.722 \\
(-0.21)\end{array}$ & $x$ & $\begin{array}{l}0.762 \\
(0.19)\end{array}$ & \\
\hline $\begin{array}{l}\text { The ratio of other real estate owned to total } \\
\text { assets interacted with the stock market excess } \\
\text { return (OREO_M) }\end{array}$ & $\begin{array}{l}-1.949 \\
(-1.38)\end{array}$ & $x$ & $\begin{array}{l}-1.806 \\
(-0.26)\end{array}$ & $x$ & $\begin{array}{l}-0.447 \\
(-0.25)\end{array}$ & $x$ & $\begin{array}{l}2.984 \\
(0.44)\end{array}$ & \\
\hline $\begin{array}{l}\text { The absolute value of the difference between } \\
\text { assets and liabilities maturing or repricing } \\
\text { within one year as a proportion of equity value } \\
\text { interated with the stock market excess return } \\
\text { (AGAP_M) }\end{array}$ & $\begin{array}{r}-0.0001 \\
(-0.15)\end{array}$ & $x$ & $\begin{array}{l}0.001 \\
(0.15)\end{array}$ & & $\begin{array}{l}0.001 \\
(0.67)\end{array}$ & & $\begin{array}{l}-0.002 \\
(-0.42)\end{array}$ & $\mathrm{x}$ \\
\hline $\begin{array}{l}\text { The ratio of total book liabilities to the sum of } \\
\text { the market value of common stock and the book } \\
\text { value of preferred stock interacted with the stock } \\
\text { market excess return (MKTLEV_M) }\end{array}$ & $\begin{array}{l}0.002 \\
(1.16)\end{array}$ & & $\begin{array}{l}-0.002 \\
(-0.60)\end{array}$ & $x$ & $\begin{array}{l}0.002 \\
(1.11)\end{array}$ & & $\begin{array}{l}0.003 \\
(0.93)\end{array}$ & \\
\hline
\end{tabular}


Table 3.3 Continued

\begin{tabular}{|c|c|c|c|c|c|c|c|c|}
\hline \multirow{3}{*}{ Explanatory Variables } & \multicolumn{8}{|c|}{ Dependent Variable / Deposit Insurance Regime } \\
\hline & \multicolumn{4}{|c|}{ Subordinated Issuance } & \multicolumn{4}{|c|}{ Senior Issuance } \\
\hline & $\begin{array}{c}\text { Pre-FDICIA } \\
\text { 85:Q1-92:04 } \\
\end{array}$ & $\begin{array}{c}\text { Expected } \\
\text { Sign? } \\
\end{array}$ & $\begin{array}{l}\text { Post-FDICIA } \\
\text { 93:-11-02:04 } \\
\end{array}$ & $\begin{array}{c}\text { Expected } \\
\text { Sign? }\end{array}$ & $\begin{array}{c}\text { Pre-FDICIA } \\
\text { 85:Q1-92:04 } \\
\end{array}$ & $\begin{array}{c}\text { Expected } \\
\text { Sign? }\end{array}$ & $\begin{array}{l}\text { Post-FDICIA } \\
\text { 93:01-02:04 } \\
\end{array}$ & $\begin{array}{c}\begin{array}{c}\text { Expected } \\
\text { Sign? }\end{array} \\
\end{array}$ \\
\hline \multicolumn{9}{|l|}{$\begin{array}{l}\text { Other Banking Organization- } \\
\text { Specific Factors }\end{array}$} \\
\hline The natural $\log$ of total assets $(\ln ($ ASSETS $))$ & $\begin{array}{l}0.574 \\
(7.29)\end{array}$ & $x$ & $\begin{array}{c}0.552 \\
(11.54)\end{array}$ & $x$ & $\begin{array}{l}0.821 \\
(8.52)\end{array}$ & $x$ & $\begin{array}{l}0.297 \\
(6.16)\end{array}$ & $x$ \\
\hline $\begin{array}{l}\text { An indicator variable that equals one if the } \\
\text { banking organization issued debt in the same } \\
\text { seniority grade in the preceding } 6 \text { month period, } \\
\text { and zero otherwise (ISSUE_- } 1 \text { ) }\end{array}$ & $\begin{array}{l}0.395 \\
(3.31)\end{array}$ & $x$ & $\begin{array}{l}0.733 \\
(8.42)\end{array}$ & $x$ & $\begin{array}{l}0.727 \\
(5.95)\end{array}$ & $x$ & $\begin{array}{c}1.585 \\
(17.22)\end{array}$ & $x$ \\
\hline $\begin{array}{l}\text { Foreign and domestic income taxes as a } \\
\text { percentage of net income (AVGTAX) }\end{array}$ & $\begin{array}{l}0.0001 \\
(1.06)\end{array}$ & $x$ & $\begin{array}{c}-0.0003 \\
(-1.27)\end{array}$ & & $\begin{array}{r}-0.0001 \\
(-0.38)\end{array}$ & & $\begin{array}{c}-0.0002 \\
(-0.59)\end{array}$ & \\
\hline $\begin{array}{l}\text { The ratio of book equity to book total assets } \\
\text { (KA) }\end{array}$ & $\begin{array}{l}-4.359 \\
(-0.66)\end{array}$ & & $\begin{array}{l}-1.838 \\
(-0.57)\end{array}$ & & $\begin{array}{l}-7.956 \\
(-1.17)\end{array}$ & & $\begin{array}{l}4.459 \\
(1.44)\end{array}$ & $x$ \\
\hline \multicolumn{9}{|l|}{ Business and Bond Market Conditions } \\
\hline The unemployment rate (UE) & $\begin{array}{l}-0.028 \\
(-0.11)\end{array}$ & $x$ & $\begin{array}{l}0.541 \\
(2.86)\end{array}$ & & $\begin{array}{l}0.045 \\
(0.17)\end{array}$ & & $\begin{array}{l}0.271 \\
(1.34)\end{array}$ & \\
\hline Stock Market Excess Return (XR) & $\begin{array}{l}-0.024 \\
(-1.41)\end{array}$ & $x$ & $\begin{array}{l}-0.002 \\
(-0.11)\end{array}$ & $x$ & $\begin{array}{l}-0.009 \\
(-0.48)\end{array}$ & $x$ & $\begin{array}{l}-0.017 \\
(-0.81)\end{array}$ & $x$ \\
\hline $\begin{array}{l}\text { The implied stock volatility measure calculated } \\
\text { from option prices traded on the Chicago Board } \\
\text { Option Exchange (MKTVOL) }\end{array}$ & $\begin{array}{l}-0.051 \\
(-2.58)\end{array}$ & $x$ & $\begin{array}{l}-0.004 \\
(-0.21)\end{array}$ & $x$ & $\begin{array}{l}0.002 \\
(0.13)\end{array}$ & & $\begin{array}{l}0.010 \\
(0.57)\end{array}$ & \\
\hline \multicolumn{9}{|l|}{ Supervisory Pressure } \\
\hline $\begin{array}{l}\text { An indicator variable that equals one if the } \\
\text { composite supervisory rating equals } 2 \\
\text { (BOPEC2) }\end{array}$ & $\begin{array}{l}-0.138 \\
(-1.25)\end{array}$ & $x$ & $\begin{array}{l}0.049 \\
(0.56)\end{array}$ & & $\begin{array}{l}-0.025 \\
(-0.19)\end{array}$ & $x$ & $\begin{array}{l}0.209 \\
(2.24)\end{array}$ & \\
\hline $\begin{array}{l}\text { An indicator variable that equals one if the } \\
\text { composite supervisory rating equals } 3,4 \text { or } 5 \\
\text { (BOPEC } 345 \text { ) }\end{array}$ & $\begin{array}{l}-0.510 \\
(-3.05)\end{array}$ & $x$ & $\begin{array}{l}0.089 \\
(0.27)\end{array}$ & & $\begin{array}{l}0.194 \\
(1.04)\end{array}$ & & $\begin{array}{l}0.424 \\
(1.42)\end{array}$ & \\
\hline \multicolumn{9}{|l|}{ Wald Tests } \\
\hline $\begin{array}{l}\text { Wald test statistic for "risk" coefficients jointly } \\
\text { equalling zero }\end{array}$ & 55.44 & & 74.70 & & 40.79 & & 67.23 & \\
\hline $\begin{array}{l}\text { Critical value for the Wald test at the } 5 \text { percent } \\
\text { confidence level }\end{array}$ & 18.3 & & 18.3 & & 18.3 & & 18.3 & \\
\hline Goodness of Fit Measures & & & & & & & & \\
\hline $\begin{array}{l}\text { Fraction of correct predictions for issuance } \\
\text { decision }\end{array}$ & 0.851 & & 0.848 & & 0.886 & & 0.880 & \\
\hline Number of Observations & 1480 & & 1933 & & 1480 & & 1933 & \\
\hline R-Squared & 0.21 & & 0.31 & & 0.21 & & 0.35 & \\
\hline Percent that issued debt of that seniority grade & 16.89 & & 21.83 & & 13.11 & & 17.43 & \\
\hline
\end{tabular}

Note: All specifications include a constant term which was significant at the $5 \%$ level. Year indicator variables, which were equal to one in a specific year of each panel, and zero otherwise were also included though these coefficient estimates are not reported here. Observed spread regressions are heteroskedastic-consistent. $t$-statistics are in parentheses. 
Table 3.4

Parameter Estimates for the Stacked Data Issuance Decision Model for
Large U.S. Banking Organizations

\begin{tabular}{|c|c|c|c|c|c|c|c|c|}
\hline \multirow{3}{*}{ Explanatory Variables } & \multicolumn{8}{|c|}{ Dependent Variable / Deposit Insurance Regime } \\
\hline & \multicolumn{4}{|c|}{ Pre-FDICIA Period } & \multicolumn{4}{|c|}{ Post-FDICIA Period } \\
\hline & $\begin{array}{c}\text { Direct Effect for } \\
\text { Subordinated Debt }\end{array}$ & $\begin{array}{c}\text { Expected } \\
\text { Sign? }\end{array}$ & $\begin{array}{c}\text { Additional Effect for } \\
\text { Senior Debt }\end{array}$ & $\begin{array}{l}\text { Expected } \\
\text { Sign? }\end{array}$ & $\begin{array}{c}\text { Direct Effect for } \\
\text { Subordinated Debt }\end{array}$ & $\begin{array}{c}\text { Expected } \\
\text { Sign? }\end{array}$ & $\begin{array}{c}\text { Additional Effect for } \\
\text { Senior Debt }\end{array}$ & $\begin{array}{c}\text { Expected } \\
\text { Sign? }\end{array}$ \\
\hline $\begin{array}{l}\text { Accounting-and Market- } \\
\text { based Risk Measures }\end{array}$ & & & & & & & & \\
\hline $\begin{array}{l}\text { The ratio of non-accruing loans to total assets } \\
\text { (NATA) }\end{array}$ & $\begin{array}{l}-8.474 \\
(-1.39)\end{array}$ & $x$ & $\begin{array}{l}-9.217 \\
(-1.04)\end{array}$ & $x$ & $\begin{array}{l}-9.828 \\
(-0.78)\end{array}$ & $x$ & $\begin{array}{r}29.830 \\
(1.71)\end{array}$ & \\
\hline $\begin{array}{l}\text { The ratio of accruing loans past due } 90 \text { days } \\
\text { of more to total assets (PDTA) }\end{array}$ & $\begin{array}{c}-49.698 \\
(-1.86)\end{array}$ & $x$ & $\begin{array}{c}109.530 \\
(3.03)\end{array}$ & & $\begin{array}{l}9.831 \\
(0.38)\end{array}$ & & $\begin{array}{c}-36.950 \\
(-1.00)\end{array}$ & $x$ \\
\hline $\begin{array}{l}\text { The ratio of other real estate owned to total } \\
\text { assets (OREO) }\end{array}$ & $\begin{array}{c}14.103 \\
(1.01)\end{array}$ & & $\begin{array}{r}-40.190 \\
(-1.89)\end{array}$ & $x$ & $\begin{array}{c}33.754 \\
(1.22)\end{array}$ & & $\begin{array}{c}-99.285 \\
(-2.44)\end{array}$ & $x$ \\
\hline $\begin{array}{l}\text { The absolute value of the difference between } \\
\text { assets and liabilities maturing or repricing } \\
\text { within one year as a proportion of equity } \\
\text { value (AGAP) }\end{array}$ & $\begin{array}{l}-0.001 \\
(-0.27)\end{array}$ & $x$ & $\begin{array}{l}0.004 \\
(0.76)\end{array}$ & & $\begin{array}{l}-0.028 \\
(-1.12)\end{array}$ & $x$ & $\begin{array}{l}-0.013 \\
(-0.29)\end{array}$ & $\mathrm{x}$ \\
\hline $\begin{array}{l}\text { The ratio of total book liabilities to the sum of } \\
\text { the market value of common stock and the } \\
\text { book value of preferred stock (MKTLEV) } \\
\text { Accounting- and Market- based } \\
\text { Risk Measures Interacted with } \\
\text { the Stock Market Excess Returns }\end{array}$ & $\begin{array}{l}0.013 \\
(1.03)\end{array}$ & $\mathrm{x}$ & $\begin{array}{l}-0.043 \\
(-2.67)\end{array}$ & $x$ & $\begin{array}{l}0.014 \\
(0.57)\end{array}$ & & $\begin{array}{l}-0.030 \\
(-0.96)\end{array}$ & $\mathrm{x}$ \\
\hline $\begin{array}{l}\text { The ratio of non-accruing loans to total assets } \\
\text { interacted with the stock market excess return } \\
\text { (NATA_M) }\end{array}$ & $\begin{array}{l}-1.207 \\
(-1.96)\end{array}$ & $x$ & $\begin{array}{l}1.003 \\
(1.07)\end{array}$ & & $\begin{array}{l}0.289 \\
(0.11)\end{array}$ & & $\begin{array}{l}0.711 \\
(0.20)\end{array}$ & \\
\hline $\begin{array}{l}\text { The ratio of accruing loans past due } 90 \text { days } \\
\text { of more to total assets interacted with the } \\
\text { stock market excess return (PDTA_M) }\end{array}$ & $\begin{array}{l}7.899 \\
(2.36)\end{array}$ & & $\begin{array}{l}-8.592 \\
(-1.84)\end{array}$ & $x$ & $\begin{array}{l}-1.304 \\
(-0.31)\end{array}$ & $x$ & $\begin{array}{l}2.190 \\
(0.37)\end{array}$ & \\
\hline $\begin{array}{l}\text { The ratio of other real estate owned to total } \\
\text { assets interacted with the stock market excess } \\
\text { return (OREO_M) }\end{array}$ & $\begin{array}{l}-2.113 \\
(-1.49)\end{array}$ & $x$ & $\begin{array}{l}1.079 \\
(0.48)\end{array}$ & & $\begin{array}{l}0.486 \\
(0.07)\end{array}$ & & $\begin{array}{l}-1.431 \\
(-0.15)\end{array}$ & $x$ \\
\hline $\begin{array}{l}\text { The absolute value of the difference between } \\
\text { assets and liabilities maturing or repricing } \\
\text { within one year as a proportion of equity } \\
\text { value interated with the stock market excess } \\
\text { return (AGAP_M) }\end{array}$ & $\begin{array}{c}-0.00002 \\
(-0.02)\end{array}$ & $x$ & $\begin{array}{l}0.001 \\
(0.53)\end{array}$ & & $\begin{array}{l}0.0004 \\
(0.12)\end{array}$ & & $\begin{array}{l}-0.002 \\
(-0.44)\end{array}$ & $x$ \\
\hline $\begin{array}{l}\text { The ratio of total book liabilities to the sum of } \\
\text { the market value of common stock and the } \\
\text { book value of preferred stock interacted with } \\
\text { the stock market excess return (MKTLEV_M) }\end{array}$ & $\begin{array}{l}0.003 \\
(1.84)\end{array}$ & & $\begin{array}{l}-0.002 \\
(-0.64)\end{array}$ & $x$ & $\begin{array}{l}-0.001 \\
(-0.33)\end{array}$ & $x$ & $\begin{array}{l}0.003 \\
(0.72)\end{array}$ & \\
\hline
\end{tabular}


Table 3.4 Continued

\begin{tabular}{|c|c|c|c|c|c|c|c|c|}
\hline \multirow{2}{*}{ Explanatory Variables } & \multicolumn{4}{|c|}{ Pre-FDICIA Period } & \multicolumn{4}{|c|}{ Post-FDICIA Period } \\
\hline & $\begin{array}{c}\text { Direct Effect for } \\
\text { Subordinated Debt } \\
\end{array}$ & $\begin{array}{c}\text { Expected } \\
\text { Sign? }\end{array}$ & $\begin{array}{c}\text { Additional Effect for } \\
\text { Senior Debt }\end{array}$ & $\begin{array}{c}\text { Expected } \\
\text { Sign? }\end{array}$ & $\begin{array}{c}\text { Direct Effect for } \\
\text { Subordinated Debt } \\
\end{array}$ & $\begin{array}{l}\text { Expected } \\
\text { Sign? }\end{array}$ & $\begin{array}{c}\text { Additional Effect for } \\
\text { Senior Debt }\end{array}$ & $\begin{array}{c}\text { Expected } \\
\text { Sign? }\end{array}$ \\
\hline \multicolumn{9}{|l|}{$\begin{array}{l}\text { Other Banking Organization- } \\
\text { Specific Factors }\end{array}$} \\
\hline The natural log of total assets $(\ln ($ ASSETS $))$ & $\begin{array}{c}0.653 \\
(10.50)\end{array}$ & $x$ & $\begin{array}{l}0.027 \\
(0.55)\end{array}$ & $x$ & $\begin{array}{c}0.469 \\
(12.40)\end{array}$ & $x$ & $\begin{array}{l}-0.091 \\
(-2.58)\end{array}$ & \\
\hline $\begin{array}{l}\text { An indicator variable that equals one if the } \\
\text { banking organization issued SND in the } \\
\text { preceding } 6 \text { month period, and zero otherwise } \\
\text { (ISSUE_-1) }\end{array}$ & $\begin{array}{l}0.423 \\
(3.68)\end{array}$ & $x$ & $\begin{array}{l}0.384 \\
(2.34)\end{array}$ & $x$ & $\begin{array}{l}0.772 \\
(9.15)\end{array}$ & $x$ & $\begin{array}{l}0.782 \\
(6.33)\end{array}$ & $x$ \\
\hline $\begin{array}{l}\text { Foreign and domestic income taxes as a } \\
\text { percentage of net income (AVGTAX) }\end{array}$ & $\begin{array}{l}0.0001 \\
(1.01)\end{array}$ & $x$ & $\begin{array}{c}-0.0001 \\
(-0.82)\end{array}$ & & $\begin{array}{c}-0.0003 \\
(-1.23)\end{array}$ & & $\begin{array}{l}0.0001 \\
(0.27)\end{array}$ & $x$ \\
\hline $\begin{array}{l}\text { The ratio of book equity to book total assets } \\
\text { (KA) }\end{array}$ & $\begin{array}{l}8.097 \\
(1.44)\end{array}$ & $x$ & $\begin{array}{l}-25.711 \\
(-3.55)\end{array}$ & & $\begin{array}{l}-4.227 \\
(-1.42)\end{array}$ & $\mathrm{X}$ & $\begin{array}{l}11.216 \\
(2.95)\end{array}$ & $x$ \\
\hline \multicolumn{9}{|l|}{$\begin{array}{l}\text { Business and Bond Market } \\
\text { Conditions }\end{array}$} \\
\hline The unemployment rate (UE) & $\begin{array}{l}-0.361 \\
(-2.43)\end{array}$ & $x$ & $\begin{array}{l}0.010 \\
(0.11)\end{array}$ & & $\begin{array}{l}0.397 \\
(2.78)\end{array}$ & & $\begin{array}{l}0.015 \\
(0.19)\end{array}$ & \\
\hline Stock Market Excess Return (XR) & $\begin{array}{l}-0.024 \\
(-1.43)\end{array}$ & $x$ & $\begin{array}{l}0.024 \\
(0.96)\end{array}$ & & $\begin{array}{l}-0.006 \\
(-0.34)\end{array}$ & $\mathrm{X}$ & $\begin{array}{l}-0.006 \\
(-0.21)\end{array}$ & $x$ \\
\hline $\begin{array}{l}\text { The implied stock volatility measure } \\
\text { calculated from option prices traded on the } \\
\text { Chicago Board Option Exchange (MKTVOL) }\end{array}$ & $\begin{array}{l}-0.047 \\
(-3.05)\end{array}$ & $x$ & $\begin{array}{l}0.062 \\
(3.78)\end{array}$ & & $\begin{array}{l}-0.006 \\
(-0.43)\end{array}$ & $\mathrm{X}$ & $\begin{array}{l}0.019 \\
(1.37)\end{array}$ & \\
\hline \multicolumn{9}{|l|}{ Supervisory Pressure } \\
\hline $\begin{array}{l}\text { An indicator variable that equals one if the } \\
\text { composite supervisory rating equals } 2 \\
\text { (BOPEC2) }\end{array}$ & $\begin{array}{l}0.007 \\
(0.06)\end{array}$ & & $\begin{array}{l}-0.201 \\
(-1.30)\end{array}$ & $x$ & $\begin{array}{l}0.044 \\
(0.53)\end{array}$ & & $\begin{array}{l}0.185 \\
(1.53)\end{array}$ & \\
\hline $\begin{array}{l}\text { An indicator variable that equals one if the } \\
\text { composite supervisory rating equals } 3,4 \text { or } 5 \\
\text { (BOPEC } 345 \text { ) }\end{array}$ & $\begin{array}{l}-0.293 \\
(-1.81)\end{array}$ & $x$ & $\begin{array}{l}0.263 \\
(1.16)\end{array}$ & & $\begin{array}{l}0.071 \\
(0.22)\end{array}$ & & $\begin{array}{l}0.397 \\
(0.93)\end{array}$ & \\
\hline \multicolumn{9}{|l|}{ Goodness of Fit Measures } \\
\hline $\begin{array}{l}\text { Fraction of correct predictions for issuance } \\
\text { decision }\end{array}$ & 0.870 & & & & 0.865 & & & \\
\hline Number of Observations & 2960 & & & & 3866 & & & \\
\hline R-Squared & 0.202 & & & & 0.325 & & & \\
\hline Percent that issued debt instrument & 16.89 & & 21.83 & & 13.11 & & 17.43 & \\
\hline
\end{tabular}

Note: All specifications include a constant term which was significant at the 5\% level. Year indicator variables, which were equal to one in a specific year of each panel, and zero otherwise were also included though these coefficient estimates are not reported here. Observed spread regressions are heteroskedastic-consistent. $\mathrm{t}$-statistics are in parentheses. 
more likely to issue debt than are less well capitalized organizations.

In the pre-FDICIA period, at least three out of five of the banking organizationspecific variables have the expected sign for either subordinated or senior issues. A Wald test (Table 3.5) for the joint impact of these five variables yields a (nonsignificant) negative result for subordinated issues and a significant positive result for senior issues. This implies that banks with negative news tended to issue senior debt during this period. Interestingly, among the individual coefficients, the most privately known, NATA and PDTA, have a negative sign in the column for subordinated issues, while one of the publicly accessible variables, $M K T L E V$ has a negative sign and is statistically significant in the column for senior issuance. ${ }^{39}$ These results suggest that banks' preference for senior debt in times of relatively adverse information is stronger when bad news is private than when bad news is public. Moreover, the general preference for subordinated debt in good, and senior debt in bad times is confirmed by the proxies for public risk perception: parameter estimates for $U E$ and $M K T V O L$ are both negative and the estimate for MKTVOL is significantly negative for subordinated debt in this period. And, the significant and negative parameter estimate for BOPEC345 during this period further confirms that the riskiest banks did not take advantage of adverse insider information by issuing subordinated debt. In contrast, the market price of risk $(X R)$ is not significant, nor are the joint impact of the interaction terms with banking organization-specific risk variables (these interacted variables are marked by the suffix _ $M$ ) significant. ${ }^{40}$

Taken together, these empirical findings mean that the "informed investor hypothesis" is well confirmed by the data in the pre-FDICIA period. In times of unfavorable information, banks do not, or cannot issue subordinated debt. Or, subordinated debt may be efficiently priced while senior debt is underpriced in bad times. In addition, we find scant evidence to support the "risk aversion hypothesis." Moreover, the "signalling hypothesis," which would predict more subordinated issues in times when banks have bad private information, is clearly rejected for this period.

In the post-FDICIA period, four out of five of the banking organizationspecific risk variables have a sign that is consistent with the substitution effect between subordinated and senior debt that was detected in the pre-FDICIA period. ${ }^{41}$ However, in the post-FDICIA period the joint impact of these variables ceases to be significant in a Wald test (Table 3.5) and the direction of the impact even changes signs. ${ }^{42}$

In the post-FDICIA period, the effects of bond and business market con-

\footnotetext{
${ }^{39}$ In the stacked data model, Table 3.4 , the senior debt indicator interacted risk variables for PDTA and MARKTLEV are statistically significant in opposing directions.

${ }^{40} \mathrm{~A}$ Wald test for the joint effect of the interacted terms yields a positive sign for subordinated debt and a negative sign for senior debt, neither of which is significant.

${ }^{41}$ In the stacked data models, only one of the parameter estimates for senior debt banking organization-specific risk variables $(O R E O)$ was significantly different from subordinated debt banking organization-specific risk variables in the post-FDICIA period.

${ }^{42}$ These findings were also confirmed using a multinomial logit regression model where banking organizations could chose to (1) issue no public debt, (2) to issue only senior debt, (3) to issue only subordinated debt, or (4) to issue both senior and subordinated debt instruments. The joint marginal effects of the banking organization-specific risk proxies and of said risk proxies interacted with the market price of risk were of the same signs as were obtained using the separate probit models in each period that are reported in Table 3.3. Therefore, the parameter estimates for the logit model support the view that banking organizations substitute between senior and subordinated debt issuance activities as their financial condition evolves.
} 
Table 3.5

Hypotheses, Wald Test Statistics, Critical Values and Sign Tests for Joint Effects in the Issuance Decision Models

\begin{tabular}{|c|c|c|c|c|c|c|}
\hline \multirow[b]{2}{*}{ Hypothesis } & \multicolumn{3}{|c|}{ Pre-FDICIA Period: 1985:Q1 - 1992:Q4 } & \multicolumn{3}{|c|}{ Post-FDICIA Period: 1993:Q1 - 2002:Q4 } \\
\hline & $\begin{array}{c}\text { Test } \\
\text { Statistic }\end{array}$ & $\begin{array}{l}\text { Critical Value for } \\
\text { a } 5 \text { Percent } \\
\text { Confidence Level }\end{array}$ & $\begin{array}{l}\text { Joint } \\
\text { Effect }\end{array}$ & $\begin{array}{c}\text { Test } \\
\text { Statistic }\end{array}$ & $\begin{array}{l}\text { Critical Value for } \\
\text { a } 5 \text { Percent } \\
\text { Confidence Level }\end{array}$ & $\begin{array}{l}\text { Joint } \\
\text { Effect }\end{array}$ \\
\hline $\begin{array}{l}\text { H1: The parameter estimates for accounting- } \\
\text { and market-based risk variables jointly } \\
\text { equal zero in the model for } \\
\text { subordinated debt. }\end{array}$ & 4.24 & 11.1 & Negative & 9.06 & 11.1 & Positive \\
\hline $\begin{aligned} \text { H2: The parameter estimates for accounting- } \\
\text { and market-based risk variables jointly } \\
\text { equal zero in the model for } \\
\text { senior debt. }\end{aligned}$ & 30.00 & 11.1 & Positive & 10.36 & 11.1 & Negative \\
\hline
\end{tabular}


ditions and of private information on debt issuance decisions are either fairly weak or quite unexpected. Although bond market volatility significantly reduced subordinated debt issuance activities in the pre-FDICIA period, the parameter estimate for $M K T V O L$ was insignificant in the post-FDICIA period. Moreover, such activities were (unexpectedly) positively correlated with the unemployment rate $(U E)$ in the post-FDICIA period. Interestingly, the supervisory indicator variables did not influence subordinated debt issuance activities in the post-FDICIA period, but BOPEC2 significantly influenced senior debt issuance activities, though this effect was not substantially different in the stacked issuance model (Table 3.4). ${ }^{43}$

Taken together, the issuance decision parameter estimates confirm our expectation that senior and subordinated debt would become more similar under recent the regulatory reforms that implemented depositor preference and capital-based prompt corrective actions by bank supervisors. Publicly perceived risk does not appear to favor senior over subordinated debt any more. Only the most private bad information (represented by the $B O P E C$ variables) still prompts banking organizations to prefer to issue senior debt.

\subsubsection{Issuance spreads}

Table 3.6 presents parameter estimates for the sample selection models for subordinated and senior debt spreads, equation (25). These models were estimated for the pre-FDICIA (1985:Q1- 1992:Q4) and post-FDICIA (1993:Q1-2002:Q4) periods using data on issuance spreads for all subordindated instruments, for only subordinated instruments with an issuance size of at least $\$ 75$ million USD, and for all senior instruments issued by large U.S. banking organizations. As with Tables 3.3 and 3.4, the left column of the table provides a short description for each of the explanatory variables. The left panel of the table presents estimates for the sample selection model for subordinated debt during each of the time periods considered, and the right panel of the table presents estimates for the sample selection model for senior debt during each of the time periods considered. And, Table 3.7 presents parameter estimates for the stacked data sample selection models. The dependent variables for the stacked sample selection model are the stacked observed issuance spreads for subordinated $\left(S P R E A D_{U, i, t}\right)$ and for senior debt $\left(S P R E A D_{E, i, t}\right)$. Parameter estimates for the explanatory variables interacted with a senior grade indicator variable, $I$, in Table 3.7 are significant only when the individual parameter estimates for the original sample selection models (in Table 3.6) are statistically different when senior debt market data, rather than subordinated debt market data, are used. Thus, parameter estimates in the stacked regression can be used to infer a "direct effect" for subordianted debt and an "additional effect" for senior debt. Wald test statistics are presented in Table 3.8 for the joint impact of groups of risk varaibles on issuance spreads.

Yield spreads in both the pre- and post-FDICIA periods were strongly influenced by instrument-specific characteristics such as call options, $C A L L$, maturities (MATLT10, MATGT20), and coupon frequencies (COUPON2). Although it appears that the largest banks among the 50 largest banks paid higher senior spreads in the pre-FDICIA period and lower senior spreads in the post-FDICIA

\footnotetext{
${ }^{43}$ The logit model parameter estimates for the BOPEC variables were also consistent with the probit model parameter estimates that are reported in Table 3.3.
} 
Table 3.6

\section{Parameter Estimates for the Sample Selection Model of Large U.S. Banking Organizations}

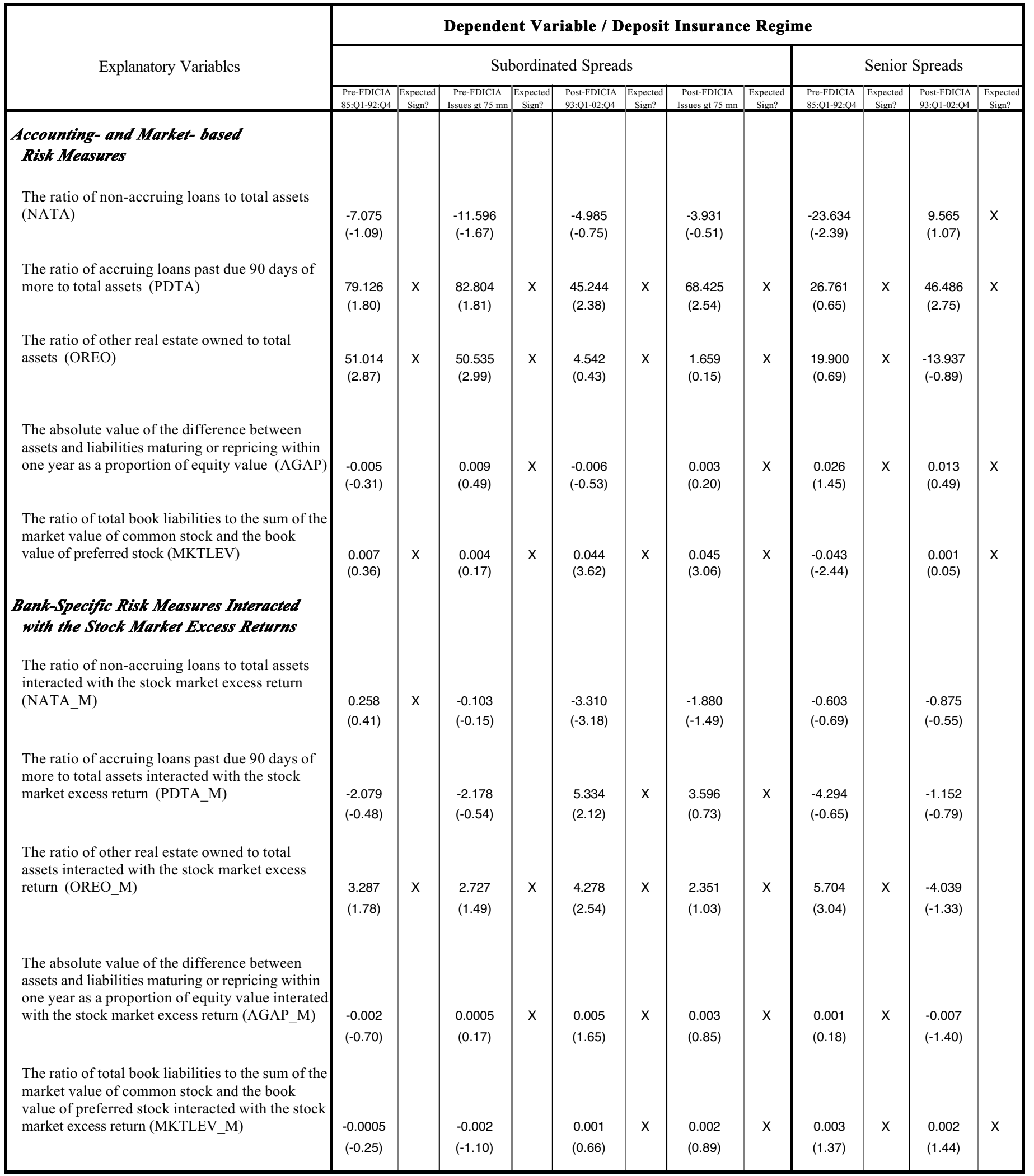


Table 3.6 Continued

\begin{tabular}{|c|c|c|c|c|c|c|c|c|c|c|c|c|}
\hline \multirow{3}{*}{ Explanatory Variables } & \multicolumn{12}{|c|}{ Dependent Variable / Deposit Insurance Regime } \\
\hline & \multicolumn{8}{|c|}{ Subordinated Spreads } & \multicolumn{4}{|c|}{ Senior Spreads } \\
\hline & $\begin{array}{l}\text { Pre-FDICIA } \\
\text { 85:Q1-92:Q4 } \\
\end{array}$ & $\begin{array}{c}\text { Expected } \\
\text { Sign? } \\
\end{array}$ & \begin{tabular}{|c|} 
Pre-FDICIA \\
Issues gt $75 \mathrm{~mm}$ \\
\end{tabular} & \begin{tabular}{|l|} 
Expected \\
Sign? \\
\end{tabular} & $\begin{array}{l}\text { Post-FDICIA } \\
\text { 93:Q1-02:Q4 } \\
\end{array}$ & \begin{tabular}{c|c} 
Expected \\
Sign?
\end{tabular} & \begin{tabular}{|c|} 
Post-FDICIA \\
Issues gt $75 \mathrm{mn}$ \\
\end{tabular} & $\begin{array}{c}\text { Expected } \\
\text { Sign? } \\
\end{array}$ & $\begin{array}{l}\text { Pre-FDICIA } \\
\text { 85:Q1-92:Q4 } \\
\end{array}$ & \begin{tabular}{|c|} 
Expected \\
Sign?
\end{tabular} & $\begin{array}{l}\text { Post-FDICIA } \\
\text { 93:Q1-02:Q4 } \\
\end{array}$ & $\begin{array}{c}\text { Expected } \\
\text { Sign? } \\
\end{array}$ \\
\hline \multicolumn{13}{|l|}{$\begin{array}{l}\text { Other Banking Organization- } \\
\text { Specific Factors }\end{array}$} \\
\hline The natural $\log$ of total assets ( $\ln ($ ASSETS $)$ ) & $\begin{array}{l}-0.228 \\
(-0.89)\end{array}$ & $x$ & $\begin{array}{l}-0.142 \\
(-0.57)\end{array}$ & $x$ & $\begin{array}{l}0.198 \\
(1.19)\end{array}$ & & $\begin{array}{l}0.058 \\
(0.34)\end{array}$ & & $\begin{array}{l}0.894 \\
(3.20)\end{array}$ & & $\begin{array}{l}-0.084 \\
(-2.20)\end{array}$ & $x$ \\
\hline $\begin{array}{l}\text { An indicator variable that equals one if the } \\
\text { banking organization issued debt in the same } \\
\text { seniority grade in the preceding } 6 \text { month period, } \\
\text { and zero otherwise (ISSUE_-1) }\end{array}$ & $\begin{array}{l}-0.301 \\
(-1.86)\end{array}$ & $\mathrm{x}$ & $\begin{array}{l}-0.279 \\
(-1.73)\end{array}$ & $\mathrm{x}$ & $\begin{array}{l}0.200 \\
(0.82)\end{array}$ & & $\begin{array}{l}-0.028 \\
(-0.12)\end{array}$ & $\mathrm{x}$ & $\begin{array}{l}0.363 \\
(0.91)\end{array}$ & & $\begin{array}{l}-0.443 \\
(-1.67)\end{array}$ & $x$ \\
\hline \multicolumn{13}{|l|}{ Business and Bond Market Conditions } \\
\hline Stock Market Excess Return (XR) & $\begin{array}{l}0.010 \\
(0.45)\end{array}$ & & $\begin{array}{l}0.032 \\
(1.35)\end{array}$ & & $\begin{array}{l}-0.018 \\
(-1.91)\end{array}$ & $x$ & $\begin{array}{l}-0.009 \\
(-0.51)\end{array}$ & $x$ & $\begin{array}{l}-0.038 \\
(-1.40)\end{array}$ & $x$ & $\begin{array}{l}0.0101 \\
(0.80)\end{array}$ & \\
\hline $\begin{array}{l}\text { The implied stock volatility measure calculated } \\
\text { from option prices traded on the Chicago Board }\end{array}$ & & & & & & & & & & & & \\
\hline Option Exchange (MKTVOL) & $\begin{array}{l}0.077 \\
(4.34)\end{array}$ & $x$ & $\begin{array}{l}0.088 \\
(4.62)\end{array}$ & $x$ & $\begin{array}{l}0.013 \\
(1.67)\end{array}$ & $x$ & $\begin{array}{l}0.025 \\
(1.81)\end{array}$ & $x$ & $\begin{array}{l}0.015 \\
(1.59)\end{array}$ & $\mathrm{x}$ & $\begin{array}{l}0.021 \\
(2.65)\end{array}$ & $x$ \\
\hline \multicolumn{13}{|l|}{ Supervisory Pressure } \\
\hline $\begin{array}{l}\text { An indicator variable that equals one if the } \\
\text { composite supervisory rating equals } 2 \text { (BOPEC2) }\end{array}$ & $\begin{array}{l}0.368 \\
(3.18)\end{array}$ & $\mathrm{x}$ & $\begin{array}{l}0.450 \\
(3.73)\end{array}$ & $\mathrm{x}$ & $\begin{array}{l}0.083 \\
(2.47)\end{array}$ & $\mathrm{x}$ & $\begin{array}{l}0.022 \\
(0.45)\end{array}$ & $x$ & $\begin{array}{l}0.192 \\
(1.13)\end{array}$ & $x$ & $\begin{array}{l}-0.102 \\
(-2.15)\end{array}$ & \\
\hline $\begin{array}{l}\text { An indicator variable that equals one if the } \\
\text { composite supervisory rating equals } 3,4 \text { or } 5 \\
\text { (BOPEC } 345 \text { ) }\end{array}$ & $\begin{array}{l}0.7480 \\
(3.69)\end{array}$ & $x$ & $\begin{array}{l}0.7046 \\
(3.32)\end{array}$ & $x$ & $\begin{array}{l}0.0089 \\
(0.12)\end{array}$ & $x$ & $\begin{array}{l}-0.025 \\
(-0.20)\end{array}$ & & $\begin{array}{l}0.662 \\
(2.19)\end{array}$ & $x$ & $\begin{array}{l}-0.631 \\
(-2.78)\end{array}$ & \\
\hline \multicolumn{13}{|l|}{ Instrument Characteristics } \\
\hline $\begin{array}{l}\text { An indicator that equals one when an issue has a } \\
\text { call option (CALL) }\end{array}$ & $\begin{array}{l}0.317 \\
(1.13)\end{array}$ & $x$ & $\begin{array}{l}0.373 \\
(1.39)\end{array}$ & $x$ & $\begin{array}{l}0.090 \\
(2.85)\end{array}$ & $x$ & $\begin{array}{l}0.188 \\
(2.99)\end{array}$ & $x$ & $\begin{array}{r}-0.1921 \\
(-0.77)\end{array}$ & & $\begin{array}{l}0.1154 \\
(1.12)\end{array}$ & $x$ \\
\hline $\begin{array}{l}\text { An indicator that equals one when an issue has a } \\
\text { maturity less than ten years (MATLT10) }\end{array}$ & $\begin{array}{l}0.123 \\
(1.39)\end{array}$ & $x$ & $\begin{array}{l}0.157 \\
(1.76)\end{array}$ & $x$ & $\begin{array}{l}0.143 \\
(5.30)\end{array}$ & $x$ & $\begin{array}{l}0.131 \\
(3.49)\end{array}$ & $x$ & $\begin{array}{l}-0.256 \\
(-1.24)\end{array}$ & & $\begin{array}{l}0.077 \\
(1.66)\end{array}$ & $x$ \\
\hline $\begin{array}{l}\text { An indicator that equals one when an issue has a } \\
\text { maturity greater than twenty years (MATGT20) }\end{array}$ & $\begin{array}{l}0.950 \\
(3.55)\end{array}$ & $x$ & $\begin{array}{l}0.992 \\
(3.84)\end{array}$ & $x$ & $\begin{array}{l}0.126 \\
(3.97)\end{array}$ & $x$ & $\begin{array}{l}0.125 \\
(1.64)\end{array}$ & $x$ & -- & & $\begin{array}{l}0.348 \\
(3.13)\end{array}$ & $x$ \\
\hline $\begin{array}{l}\text { An indicator that equals one when the coupon } \\
\text { frequency is monthly (COUPON12) }\end{array}$ & - & & -- & & $\begin{array}{l}-0.118 \\
(-1.70)\end{array}$ & & $\begin{array}{l}-0.311 \\
(-2.01)\end{array}$ & & -- & & $\begin{array}{l}-0.052 \\
(-1.04)\end{array}$ & \\
\hline $\begin{array}{l}\text { An indicator that equals one when the coupon } \\
\text { frequency is semi-annually (COUPON2) }\end{array}$ & $\begin{array}{l}0.657 \\
(3.26)\end{array}$ & $x$ & $\begin{array}{l}0.741 \\
(3.72)\end{array}$ & $x$ & $\begin{array}{l}-0.171 \\
(-2.56)\end{array}$ & & $\begin{array}{l}-0.303 \\
(-2.45)\end{array}$ & & $\begin{array}{l}-0.248 \\
(-0.89)\end{array}$ & & $\begin{array}{l}-0.149 \\
(-2.11)\end{array}$ & \\
\hline The dollar amount of the issue (ISSUESIZE) & $\begin{array}{l}-0.001 \\
(-1.75)\end{array}$ & $x$ & $\begin{array}{l}-0.001 \\
(-1.74)\end{array}$ & $x$ & $\begin{array}{c}0.0002 \\
(2.60)\end{array}$ & & $\begin{array}{l}0.0003 \\
(3.49)\end{array}$ & & $\begin{array}{l}0.001 \\
(0.76)\end{array}$ & & $\begin{array}{c}0.0001 \\
(0.74)\end{array}$ & \\
\hline \multicolumn{13}{|l|}{ Wald Tests } \\
\hline $\begin{array}{l}\text { Wald test statistic for "risk" coefficients jointly } \\
\text { equalling zero }\end{array}$ & 30.83 & & 32.70 & & 77.45 & & 42.49 & & 44.16 & & 19.02 & \\
\hline $\begin{array}{l}\text { Critical value for the Wald test at the } 5 \text { percent } \\
\text { confidence level }\end{array}$ & 18.3 & & 18.3 & & 18.3 & & 18.3 & & 18.3 & & 18.3 & \\
\hline Mills Inverse Ratio & & & & & & & & & & & & \\
\hline Mills inverse ratio coefficient & $\begin{array}{l}-1.000 \\
(-1.72)\end{array}$ & & $\begin{array}{l}-0.831 \\
(-1.50)\end{array}$ & & $\begin{array}{l}0.647 \\
(1.35)\end{array}$ & & $\begin{array}{l}0.240 \\
(0.52)\end{array}$ & & $\begin{array}{l}1.368 \\
(2.33)\end{array}$ & & $\begin{array}{l}-0.406 \\
(-1.67)\end{array}$ & \\
\hline \multicolumn{13}{|l|}{ Goodness of Fit Measures } \\
\hline Number of Observations & 158 & & 151 & & 735 & & 232 & & 104 & & 712 & \\
\hline R-Squared & 0.74 & & 0.75 & & 0.61 & & 0.69 & & 0.81 & & 0.249 & \\
\hline
\end{tabular}

Note: All specifications include a constant term which was significant at the $5 \%$ level. Year indicator variables, which were equal to one in a specific year of each panel, and zero otherwise were also included though these coefficient estimates are not reported here. Observed spread regressions are heteroskedastic-consistent. t-statistics are in parentheses. 
Table 3.7

Parameter Estimates for the Stacked Data Sample Selection Model for Debt Spreads of Large U.S. Banking Organizations

\begin{tabular}{|c|c|c|c|c|c|c|c|c|}
\hline \multirow{3}{*}{ Explanatory Variables } & \multicolumn{8}{|c|}{ Dependent Variable / Deposit Insurance Regi] } \\
\hline & \multicolumn{4}{|c|}{ Pre-FDICIA Period } & \multicolumn{4}{|c|}{ Post-FDICIA Period } \\
\hline & $\begin{array}{c}\text { Direct Effect for } \\
\text { Subordinated Debt }\end{array}$ & $\begin{array}{c}\text { Expected } \\
\text { Sign? }\end{array}$ & $\begin{array}{l}\text { Additional Effect for } \\
\text { Senior Debt }\end{array}$ & $\begin{array}{c}\text { Expected } \\
\text { Sign? }\end{array}$ & $\begin{array}{c}\text { Direct Effect for } \\
\text { Subordinated Debt }\end{array}$ & $\begin{array}{c}\text { Expected } \\
\text { Sign? }\end{array}$ & $\begin{array}{l}\text { Additional Effect for } \\
\text { Senior Debt }\end{array}$ & $\begin{array}{c}\text { Expected } \\
\text { Sign? }\end{array}$ \\
\hline $\begin{array}{l}\text { Accounting-and Market- } \\
\text { based Risk Measures } \\
\text { The ratio of non-accruing loans to total assets } \\
\text { (NATA) }\end{array}$ & $\begin{array}{l}-9.209 \\
(-1.47)\end{array}$ & & $\begin{array}{l}-1.644 \\
(-0.14)\end{array}$ & & $\begin{array}{c}-10.300 \\
(-1.61)\end{array}$ & & $\begin{array}{c}44.070 \\
(3.69)\end{array}$ & $\mathrm{x}$ \\
\hline $\begin{array}{l}\text { The ratio of accruing loans past due } 90 \text { days of } \\
\text { more to total assets (PDTA) }\end{array}$ & $\begin{array}{c}33.034 \\
(0.96)\end{array}$ & $x$ & $\begin{array}{c}-63.790 \\
(-1.22)\end{array}$ & & $\begin{array}{c}34.848 \\
(1.82)\end{array}$ & $x$ & $\begin{array}{c}17.523 \\
(0.67)\end{array}$ & $x$ \\
\hline $\begin{array}{l}\text { The ratio of other real estate owned to total } \\
\text { assets (OREO) }\end{array}$ & $\begin{array}{c}51.083 \\
(2.67)\end{array}$ & $x$ & $\begin{array}{c}-32.388 \\
(-1.14)\end{array}$ & & $\begin{array}{c}10.737 \\
(1.14)\end{array}$ & $\mathrm{x}$ & $\begin{array}{c}-48.416 \\
(-2.80)\end{array}$ & \\
\hline $\begin{array}{l}\text { The absolute value of the difference between } \\
\text { assets and liabilities maturing or repricing } \\
\text { within one year as a proportion of equity value } \\
\text { (AGAP) }\end{array}$ & $\begin{array}{l}-0.003 \\
(-0.16)\end{array}$ & & $\begin{array}{l}0.024 \\
(1.02)\end{array}$ & $\mathrm{x}$ & $\begin{array}{l}-0.011 \\
(-0.92)\end{array}$ & & $\begin{array}{l}0.063 \\
(2.08)\end{array}$ & $\mathrm{x}$ \\
\hline $\begin{array}{l}\text { The ratio of total book liabilities to the sum of } \\
\text { the market value of common stock and the book } \\
\text { value of preferred stock (MKTLEV) } \\
\text { Accounting-and Market- based } \\
\text { Risk Measures Interacted with } \\
\text { the Stock Market Excess Returns }\end{array}$ & $\begin{array}{l}-0.003 \\
(-0.13)\end{array}$ & & $\begin{array}{l}-0.017 \\
(-0.76)\end{array}$ & & $\begin{array}{l}0.029 \\
(3.25)\end{array}$ & $x$ & $\begin{array}{l}-0.035 \\
(-2.16)\end{array}$ & \\
\hline $\begin{array}{l}\text { The ratio of non-accruing loans to total assets } \\
\text { interacted with the stock market excess return } \\
\text { (NATA_M) }\end{array}$ & $\begin{array}{l}0.152 \\
(0.21)\end{array}$ & $x$ & $\begin{array}{l}-0.051 \\
(-0.05)\end{array}$ & & $\begin{array}{l}-3.010 \\
(-2.98)\end{array}$ & & $\begin{array}{l}2.542 \\
(1.41)\end{array}$ & $x$ \\
\hline $\begin{array}{l}\text { The ratio of accruing loans past due } 90 \text { days of } \\
\text { more to total assets interacted with the stock } \\
\text { market excess return (PDTA_M) }\end{array}$ & $\begin{array}{l} \\
-2.374 \\
(-0.55)\end{array}$ & & $\begin{array}{l}-9.783 \\
(-1.21)\end{array}$ & & $\begin{array}{l}5.209 \\
(2.08)\end{array}$ & $x$ & $\begin{array}{l}-5.136 \\
(-1.81)\end{array}$ & \\
\hline $\begin{array}{l}\text { The ratio of other real estate owned to total } \\
\text { assets interacted with the stock market excess } \\
\text { return (OREO_M) }\end{array}$ & $\begin{array}{l}3.718 \\
(1.98)\end{array}$ & $x$ & $\begin{array}{l}4.002 \\
(1.68)\end{array}$ & $x$ & $\begin{array}{l}4.166 \\
(2.65)\end{array}$ & $x$ & $\begin{array}{l}-7.373 \\
(-2.24)\end{array}$ & \\
\hline $\begin{array}{l}\text { The absolute value of the difference between } \\
\text { assets and liabilities maturing or repricing } \\
\text { within one year as a proportion of equity value } \\
\text { interated with the stock market excess return } \\
\text { (AGAP_M) }\end{array}$ & $\begin{array}{l}-0.001 \\
(-0.40)\end{array}$ & & $\begin{array}{l}-0.001 \\
(-0.32)\end{array}$ & & $\begin{array}{l}0.005 \\
(1.48)\end{array}$ & $\mathrm{x}$ & $\begin{array}{l}-0.009 \\
(-1.68)\end{array}$ & \\
\hline $\begin{array}{l}\text { The ratio of total book liabilities to the sum of } \\
\text { the market value of common stock and the book } \\
\text { value of preferred stock interacted with the } \\
\text { stock market excess return (MKTLEV_M) }\end{array}$ & $\begin{array}{l}-0.001 \\
(-0.71)\end{array}$ & & $\begin{array}{l}0.004 \\
(1.37)\end{array}$ & $x$ & $\begin{array}{l}0.001 \\
(1.00)\end{array}$ & $x$ & $\begin{array}{l}0.001 \\
(0.66)\end{array}$ & $x$ \\
\hline
\end{tabular}


Table 3.7 Continued

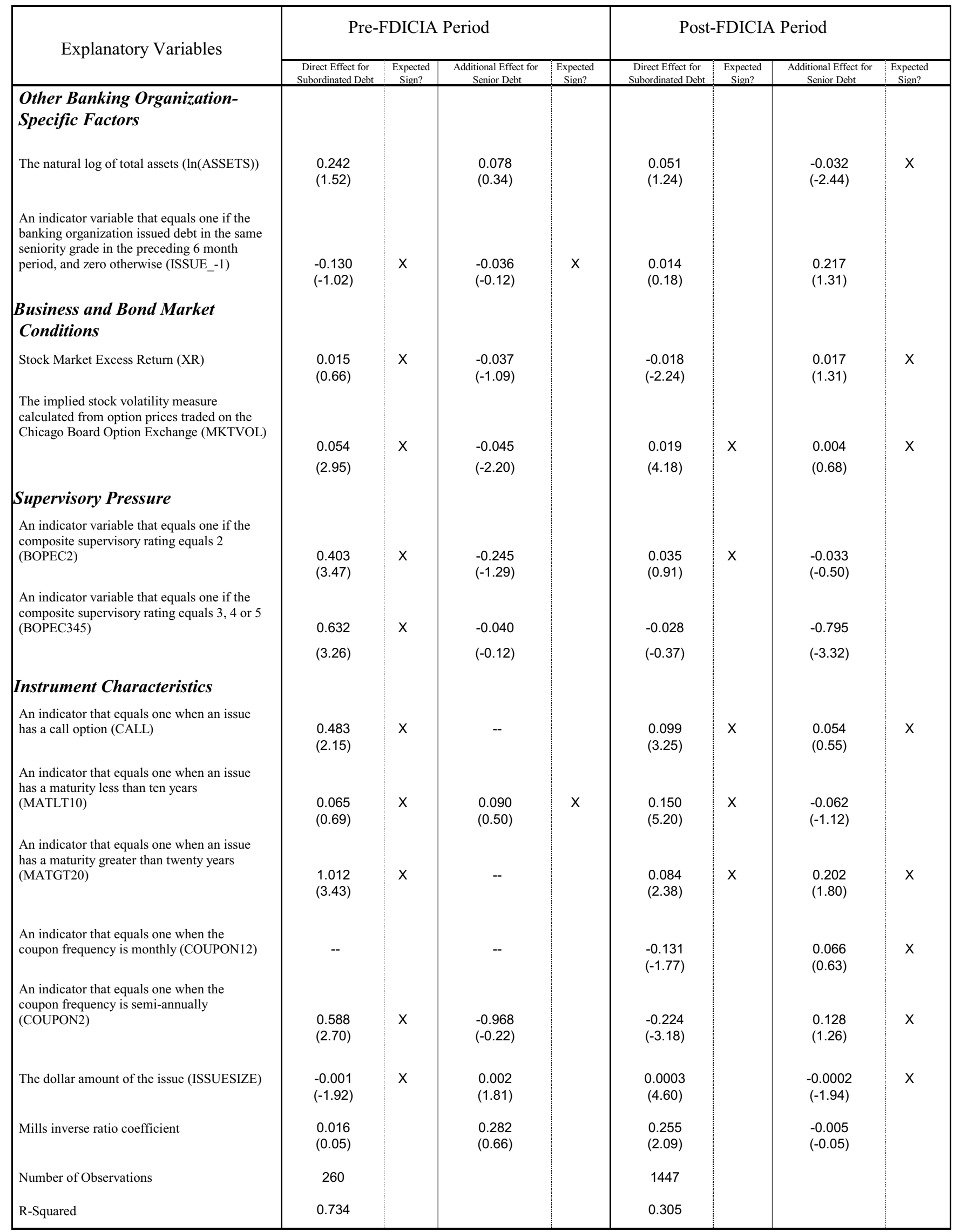

Note: All specifications include a constant term which was significant at the $5 \%$ level. Year indicator variables, which were equal to one in a specific year of each panel, and zero otherwise were also included though these coefficient estimates are not reported here. Observed spread regressions are heteroskedastic-consistent. $t$-statistics are in parentheses. 
Table 3.8

Hypotheses, Wald Test Statistics, Critical Values and Sign Tests for Joint Effects in the Sample Selection Models

\begin{tabular}{|c|c|c|c|c|c|c|}
\hline \multirow[b]{2}{*}{ Hypothesis } & \multicolumn{3}{|c|}{ Pre-FDICIA Period: 1986:Q2 - 1992:Q4 } & \multicolumn{3}{|c|}{ Post-FDICIA Period: 1993:Q1 - 1999:Q4 } \\
\hline & $\begin{array}{c}\text { Test } \\
\text { Statistic }\end{array}$ & $\begin{array}{l}\text { Critical Value for } \\
\text { a } 5 \text { Percent } \\
\text { Confidence Level }\end{array}$ & $\begin{array}{c}\text { Joint } \\
\text { Effect }\end{array}$ & $\begin{array}{c}\text { Test } \\
\text { Statistic }\end{array}$ & $\begin{array}{l}\text { Critical Value for } \\
\text { a } 5 \text { Percent } \\
\text { Confidence Level }\end{array}$ & $\begin{array}{c}\text { Joint } \\
\text { Effect }\end{array}$ \\
\hline $\begin{array}{l}\text { H1: The parameter estimates for accounting- } \\
\text { and market-based risk variables jointly } \\
\text { equal zero in the model for subordinated } \\
\text { debt spreads. } \\
\text { H2: The parameter estimates for accounting- } \\
\text { and market-based risk variables jointly } \\
\text { equal zero in the model for subordinated } \\
\text { debt spreads for issues greater than } \\
\text { \$75 million USD. } \\
\text { H3: The parameter estimates for accounting- } \\
\text { and market-based risk variables jointly } \\
\text { equal zero in the model for senior } \\
\text { debt spreads. }\end{array}$ & $\begin{array}{r}26.05 \\
28.53 \\
\\
19.37\end{array}$ & 11.1 & $\begin{array}{l}\text { Positive } \\
\text { Positive } \\
\text { Positive }\end{array}$ & $\begin{array}{r}43.85 \\
29.94 \\
12.94\end{array}$ & 11.1 & $\begin{array}{l}\text { Positive } \\
\text { Positive }\end{array}$ \\
\hline
\end{tabular}


period, we find little influence of the size of individual issues (ISSUESIZE) on senior or subordinated spreads during either period. ${ }^{44}$

In the pre-FDICIA period, for each type of instrument three out of five banking organization-specific risk variables have the expected sign (Table 3.6). Only the parameter esimate for OREO in the subordinated debt spread model is significant and of the expected sign. However, the joint effect of the five risk variables together is strongly significant and of the expected sign for both types of instruments in a Wald test (Table 3.8). In addition, the parameter estimates for the most private information among the risk variables considered (i.e., the $B O P E C \mathrm{~s}$ ) are positive for both instruments and strongly significant for subordinated debt. This means that supervisory ratings are to some degree correlated with knowledge of sophisticated investors. Poor supervisory ratings do significantly increase issuance spreads on subordinated debt.

In contrast, the price of market risk (proxied by $X R$ ) has no significant impact in this period. The parameter estimate for XR is not significantly different from zero. Moreover, the interaction variables between $X R$ and banking organization-specific risk variables are jointly insignificant for senior debt and for large and small subordinated debt issues. ${ }^{45}$

Taken together, the parameter estimates for the sample selection models in the pre-FDICIA period are largely in line with the forecasts of our model. Both, subordinated and senior spreads, do react to risk variables. While the senior spread exclusively reflects public information, the subordinate spreads react more to specialized information of the respective investors as well as to public information. This is consistent with the existence of an incentive premium and with the "informed investor hypothesis." At the same time, we find no evidence of risk aversion on the part of senior bank debt investors.

In the post-FDICIA period, three out of five of the banking organizationspecific risk variables have the expected sign in the column for subordinated debt, and four out of five of these variables have the expected sign in the column for senior debt (Table 3.6). A Wald test (Table 3.8) reveals that the joint impact of the risk proxies remains positive for both debt spreads in the post-FDICIA period, but that the joint significance level has declined for senior spreads in the pre-FDICIA period.

The parameter estimate on the private information variable, represented by the BOPECQ, remained positive and significant for subordinated debt during the post-FDICIA period. However, the magnitude of this estimate is only one fourth of the respective number for the pre-FDICIA period and the parameter estimate for BOPEC345 became both statistically and economically insignificant. Consistent with this result, the parameter estimate for $X R$ became negative and more statistically significant for subordinated spreads in the post-FDICIA period. Together these findings suggest that subordinated debt spreads became less sensitive to the private information held by subordinated investors and more sensitive to public risk perception after regulatory reforms. ${ }^{46}$

\footnotetext{
${ }^{44}$ The size of an issue may however have an impact on the sensitivity of its spread with respect to risk parameters, see below.

${ }^{45}$ Wald test statistics for the joint effect of the interacted risk variables with the market price of risk were $641,5.14$, and 10.18 for all subordinated debt issuance spreads, for suborindated debt issuance spreads on issues of at least $\$ 75$ million, and for senior debt issuance spreads, respectively. Each of these test statistics is below the 11.1 critical value for a 5 percent confidence level.

${ }^{46}$ This result may explain why practitioners complain about "ballooning" of [subordinated]
} 
The parameter estimates for interaction terms of banking organization-specific risk with the market price of risk $(X R)$ for the subordinated debt sample selection model are also interesting. Wald test statistics for the joint effect of these interaction terms suggest that the subordinated debt spreads on relatively large issues are sensitive to a simultaneous increase in bank risk and in the market price of risk, just as our model would predict. ${ }^{47}$ But Wald test statistics for this joint effect were insignificant for small subordinated issues of less than $\$ 75$ million. Perhaps, this is because smaller issues, which are frequently tranches of medium-term-note programmes, seem to cater to unsophisticated investors, rather than to investors with special knowledge on the issuing banks. While at first sight the parameter estimates on the interaction terms between the market price of risk and banking organization-specific risks appear to contradict our model, the exclusion of smaller subordinated debt issues demonstrates that these parameter estimates nicely confirm the "informed investor" hypothesis.

The parameter estimates for the senior debt sample selection model are more puzzling. Even though the banking organization-specific risk variables are jointly significant (Table 3.8), the negative and significant signs of the parameter estimates for BOPEC2 and BOPEC345 (Table 3.6) suggests that senior debt of banking organizations in poor financial condition may be chronically underpriced. This may partly explain banking organizations' preference to issue such debt when they have negative private information. It is also noteworthy that there was no sign of risk aversion of senior investors in this period either.

\section{Discussion}

Our estimation of issuance decision models for subordinated and senior debt demonstrate that U.S. banking organizations issue subordinated debt upon receipt of good news and senior debt upon receipt of bad news. In the pre-FDICIA period, both public and private information contribute to this effect. In the postFDICIA period, public information has less impact on banking organizations' choice among debt instruments, while private information remains influential, favoring subordinated (senior) debt when news is good (bad).

These results are consistent with the "informed investor hypothesis" that claims that banking organizations would issue debt of different priority status to separate investors with different, yet unobservable, beliefs on the probability of bank failure. In contrast, we found no statistical evidence that there were differences in risk aversion across investor groups. Moreover, the "signalling hypothesis" (Barclay and Smith, 1995) is clearly rejected. The data simply do not support the view that banking organizations issue subordinated debt when they have adverse private information (i.e., when subordinated debt is most overvalued). Thus, U.S. banking organizations do not appear to exploit their informational advantage over investors by opportunistic choice of debt instruments.

The lack of evidence to support opportunistic debt issuance does not neces-

spreads in bad times "reflecting broad skepticism regarding the financial health of banking institutions." (BoG, 1999, p. 16)

${ }^{47}$ The Wald test statistic is 31.66 compared to a 11.1 (95 percent) critical level. And the sign test for the joint effects of the interacted bank-specific risk variables with the market price of risk was positive in the post-FDICIA period. 
sarily imply that banking organizations behave "idealistically." One reason why banking organizations prefer to issue senior debt in bad times may be because senior debt issues are underpriced. Our empirical findings suggest that the senior spread does not react much to bad private, or specialist, information. In fact, the negative BOPEC coefficients in the post-FDICIA period imply that the senior spread may even fall when private news turns bad. It seems that banking organizations with poor supervisory ratings have managed to issue senior debt cheaply in the post-FDICIA period. ${ }^{48}$ In contrast, publicly available information did affect the senior spread in both the pre- and post-FDICIA periods.

The subordinated debt spread reacted to both public and specialist, or private, information in the pre-FDICIA period. In the post-FDICIA period, the subordinated spread became less sensitive to specialist, or private, information (proxied by supervisory ratings), but even more sensitive to public information (proxied by stock market excess returns). In the language of our model, this means that the incentive premium has become quantitatively more important.

Because regulatory reforms implemented after the last recession have influenced the size of the incentive premium, it is important to recognize that it would be inappropriate to use information on subordinated debt spreads from the pre-FDICIA period to either set a regulatory ceiling on banks' subordinated debt yield (see Calomiris, 1999) or to set triggers for prompt corrective actions (see Evanoff and Wall, 2000 and 2001; Lang and Robertson, 2000). On the one hand, the probability of failure has been reduced because of the implementation of prompt corrective actions by bank supervisors. Such reforms would likely have reduced the incentive premium. On the other hand, depositor preference rules subordinate the senior debt investors to depositors and such reforms would boost the incentive premium. Because it is highly unlikely that these two effects would exactly cancel one another out, and because our empirical results suggest that the incentive premiums contained in subordinated debt spreads are different in the pre- and post-FDICIA periods, this implies that ceilings or triggers must be set using data from only the current regulatory regime.

The stronger influence of public, rather than specialist, or private, information on subordinated debt spreads in the post-FDICIA period is likely a consequence of the implementation of depositor preference legislation. Depositor preference rules strongly subordinate senior debt to deposits and this means that expected recovery rates for senior debt issues are reduced. According to our model and to our empirical findings, the subordinated spread thus becomes responsive to public information, even though the investors who buy subordinated debt do not themselves believe the public information but hold more favorable, private views. These results explain why market practitioners complain about the "ballooning" of subordinated spreads in times of low general market confidence, or why they voice concerns about the difficulties with "disentangling the separate influences of market factors and of changes in the risk profile of a financial institution" on the subordinated debt spread. ${ }^{49}$

\footnotetext{
${ }^{48}$ One reason may be that senior investors' beliefs move with the cycle. These investors may perceive strong credit growth at a banking organization as good news when, from a supervisory or private perspective, rapid loan growth may already raise some doubts.

${ }^{49}$ BoG/DoT (2000), p.78.
} 


\section{Conclusions}

Our theoretical model buttressed by our empirical findings lead us to conclude that the yield spread on subordinated debt used in isolation has not been a straightforward measure of bank risk in either of the periods we considered. At a minimum, the subordinated yield spread does not reflect the best available information on a banking organizations' risk (e.g., the information of sophisticated, informed investors). Rather, the relation of the spread to a banking organization's true risk is blurred by its sensitivity to publicly perceived risk as, for example, to general bond market volatility or to stock market excess returns. This behavior of the subordinated spread is well in line with our model, building on the "informed investor hypothesis," and with the existence of an incentive premium between the "fair" and the measured subordinated spreads.

Paradoxically, the quality of the subordinated debt spread to measure banking organizations' risks as they are perceived by most sophisticated investors has deteriorated after the introduction of FDICIA or, more precisely, of depositor preference rules. With depositor preference rules, the risk characteristics of senior debt have become more similar to those of subordinated debt; at the same time, the subordinated debt spread has become (even) more dependent on factors influencing the senior spread.

The deterioration of the risk measurement quality of the subordinated spread after the introduction of depositor preference, however, is likely to understate the longer term virtues of the reform. Once senior debtors realize that their claims are subordinated to depositors, senior spreads may well more fully reflect specialist information. Therefore, we expect that senior debt will be held by more sophisticated investors in the future.

For these reasons, the quality of the subordinated debt spread as a measure of bank risk should not be judged on the basis of the first post-FDICIA decade. In this period, depositor preference made the subordinated spread react similarly to the senior spread without having made senior investors sufficiently risk conscious yet.

Still, our model and the empirical findings presented here suggest that the issuance spread on subordinated debt is not likely to ever reflect the best risk information present in the market, i.e. the risk perception of informed investors who buy subordinated debt. As long as subordinated debt coexists with some risky senior debt instrument, which is held by less informed (or more risk averse) investors, subordinated debt will pay an incentive premium. The incentive premium does not only remunerate sophisticated investors for the perceived risk they take by buying subordinated debt, but also for some risk they know they are not taking. Putting it differently, we might say that subordinated investors are not only remunerated for the risks they perceive in their - relatively optimistic - views, but also for the toil and trouble to become informed - and potentially optimistic - in the first place. In an equilibrium in the market for information, the incentive premium contained in the subordinated spread could thus be seen as a remuneration to become a sophisticated investor and a potential agent of market discipline. 


\section{References}

Allen, F., and D. Gale, 2000, Comparing Financial Systems, MIT Press: Cambridge, Mass., and London, England.

Barclay, M. J. and C. W. Smith, Jr., 1995, "The Priority Structure of Corporate Liabilities," The Journal of Finance, 24, 899-917.

Basel Committee on Bank Supervision (BCBS), 2001, "The New Basel Capital Accord," http://www.bis.org/publ/bcbsca03.pdf, January.

Birchler, U.W., 2000, "Bankruptcy Priority for Bank Deposits: A Contract Theoretic Explanation," Review of Financial Studies, 13, 813-839.

Board of Governors of the Federal Reserve System, 1999, "Using Subordinated Debt as an Instrument of Market Discipline," Staff Studies, no. 172, December.

Board of Governors of the Federal Reserve System and United States Department of the Treasury, 2000, The Feasability and Desirability of Mandatory Subordinated Debt, Report to the Congress, December.

Calomiris, C.W., 1999, "Building an Incentive-Compatible Safety Net," Journal of Banking and Finance, 23, 1499-1519.

Campbell, R. and R. Huisman, 2003, "Measuring Credit Spread Risk," Journal of Portfolio Management, 29, 121-127.

Collin-Dufresne, P., R.S. Goldstein, and J.S. Martin, 2001, "The Determinants of Credit Spread Changes," The Journal of Finance, 56, 2177-2207.

Covitz, D. M., D. Hancock, and M. L. Kwast, 2001, "Mandatory Subordinated Debt: Would Banks Face More Market Discipline?" mimeo, Board of Governors of the Federal Reserve System, December.

Dewatripont, M. and J. Tirole, 1994, The Prudential Regulation of Banks, The Walras-Pareto lectures, MIT Press: Cambridge, Mass.

Diamond, D. W., 1993, "Seniority and Maturity of Debt Contracts," Journal of Financial Economics, 33, 341-368.

Diether, K. B., C. J. Malloy, and A. Scherbina, 2002, "Differences of Opinion and the Cross Section of Stock Returns," The Journal of Finance, 5, 2113-2141.

Elton, E. J., M. J. Gruber, D. Agrawal and C. Mann, 2000, "Explaining the Rate Spread on Corporate Bonds," The Journal of Finance, 56, 247-277.

Evanoff, D.D. and L.D. Wall, 2000, "Subordinated Debt as Bank Capital: A Proposal for Regulatory Reform," Federal Reserve Bank of Chicago, Economic Perspectives, Second Quarter, 40-53.

Evanoff, D. D. and L. D. Wall, 2001, "Sub-debt Yield Spreads as Bank Risk Measures," Journal of Financial Services Research, 20, 121-145.

Fisher, M., D. Nychka, and D. Zervos, 1995, "Fitting the Term Structure of Interest Rates with Smoothing Splines," Finance and Economics Discussion Series, no. 1995/1, Board of Governors of the Federal Reserve System, January.

Hancock, D. and M. L. Kwast, 2001, "Using Subordinated Debt to Monitor Bank Holding Companies: Is it Feasible?," Journal of Financial Services Research, 19, December.

Krainer, J. and Lopez, J. A., 2002, "Using Equity Market Information to Monitor Banking Institutions," Federal Reserve Bank of San Francisco Economic Letter, 2003-01, January 31.

Lang, W. W. and D. D. Robertson, 2000, "A Retrospective Analysis of Subordinated Debt as a Trigger for Regulatory Intervention," mimeo, Office of the Comptroller of the Currency, December. 
Sironi, A., 2001, "An Analysis of European Banks SND Issues and its Implications for the Design of a Mandatory Subordinated Debt Policy" Journal of Financial Services Research, 20, October, 233-66.

Winton, A., 1995, "Costly State Verification and Multiple Investors: The Role of Seniority," The Review of Financial Studies, 8, 91-123. 
Swiss National Bank Working Papers published since 2004:

2004-1 Samuel Reynard: Financial Market Participation and the Apparent Instability of Money Demand

2004-2 Urs W. Birchler and Diana Hancock: What Does the Yield on Subordinated Bank Debt Measure? 
Swiss National Bank Working Papers are also available at www.snb.ch, section Publications/Research Subscriptions or individual issues can be ordered at Swiss National Bank, Fraumünsterstrasse 8, CH-8022 Zurich, phone +41 163132 84, fax +41 163181 14, E-mail library@snb.ch 